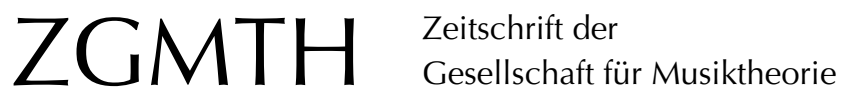

Berry, David Carson (2003/05): Schenkerian Theory in the United States. A Review of Its Establishment and a Survey of Current Research Topics. ZGMTH 1-2/2/2-3, 101137. https://doi.org/10.31751/206

C 2003/05 David Carson Berry

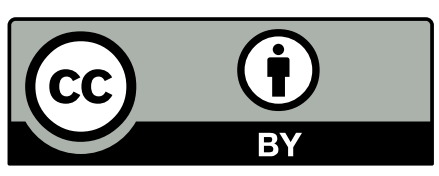

Dieser Text erscheint im Open Access und ist lizenziert unter einer Creative Commons Namensnennung 4.0 International Lizenz.

This is an open access article licensed under a Creative Commons Attribution 4.0 International License.

veröffentlicht / first published: 01/04/2005

zuletzt geändert / last updated: 01/12/2008 


\title{
Schenkerian Theory in the United States
}

\author{
A Review of Its Establishment and a Survey of Current Research \\ Topics
}

David Carson Berry

I.

It is a notable irony that the musical ideas of the Austrian Heinrich Schenker (1868-1935) have flourished most in the United States - a country about which his opinions were so low. Schenker disliked its democratic form of government because "the principle of the electoral majority" was incompatible with his belief in "the aristocratic nature of art" and culture (Schenker 1930: 111). ${ }^{1}$ He even disliked its principal language, English, calling it "motley" [verlottert] and "the lowest of the languages" [die letzte der Sprachen] (Schenker 1921: 11). ${ }^{2}$ As Carl Schachter has put it more generally, in Schenker's hierarchical belief system "[t]he Germans are ranked above all other nationalities. Other Europeans, inferior as they are to Germans, are nonetheless superior to ... Americans" (Schachter 2001:8). ${ }^{3}$ And yet, the US has established itself as the principal home for Schenkerian training and research, just as English has become its lingua franca, and Americans have become (in numeric terms) Schenker's chief advocates.

The history of how Schenkerian theory was disseminated and received in the US, during its first few decades, is still being written; aspects of that history are addressed in Berry 2002, 2003, and forthcoming -a, -b, and -c; Hinton 1998; and Rothstein 1990 and 2002. In the essay that follows, I will suggest how Schenkerian theory came to establish its strong roots in the US; how the infrastructure for its dissemination was gradually erected during the initial decades. In doing so, I will focus on four important means of transmission: the early advocates, initial institutional homes, receptive journals, and conference presentations. This, in turn, will provide a context for better understanding the

1 "Das eben macht das Aristokratische der Kunst aus, daß sie dem Grundsatz der Stimmenmehrheit, der das Alpha und Omega des demokratischen Wesens ausmacht, gar nicht zugänglich ist."

2 Obviously English could not compare to German, which Schenker regarded as "the greatest of all languages" [die höchste aller Sprachen]; but he believed that even French-which was "inferior, corsetted, [and] circumscribed" [minderwertig, gemiedert, gezirkelt]—was better than "the motley English language" [die verlotterte englische]! (Schenker 1921, 11).

3 Schachter's comments on Schenker's hierarchical belief system echo those of Martin Eybl, Ideologie und Methode: Zum ideengeschichtlichen Kontext von Schenkers Musiktheorie (Tutzing, Germany: Hans Schneider, 1995); see especially p. 29. 
second component of the article, in which I will survey the current state of English-language Schenkerian scholarship.

\section{The Transition}

Although Schenker's ideas were already circulating in the US by the early 1930s (as will be discussed below), their large-scale transplantation from Germanic lands to American shores would likely not have happened if not for the rise of Nazism, the death of Schenker, and the Austrian Anschluss. In their aftermath, many of his students-especially those who were Jewish like their teacher-fled as Schenker's work was officially censured. His writings were placed under Nazi ban and were even confiscated by the Gestapo, which seized some of his publications from Universal Editions in 1940 (Kowalke 2001:26). He and certain students were branded in the infamous Lexikon der Juden in der Musik (Stengel and Gerigk 1940/41), ${ }^{4}$ where his theory was caricatured as denying the psychological content of music in favor of "tone successions" of "arbitrary combination," and comparisons were made with the "mathematical games of the groundless musical aesthetics of the years after the [First World] War" (cols. 240-41). ${ }^{5}$ Moreover, in those rare cases in which a Germanic writer was indebted to Schenker's ideas, it seemed mandatory not only to avoid giving due credit but to distance oneself further by expressly disparaging his work; such was the case with Bernhard Martin's 1940/41 study of J.S. Bach's Art of Fugue. ${ }^{6}$

This is not to suggest that Schenker's legacy was completely eradicated from his homeland. For example, Felix-Eberhard von Cube (1903-88), who had studied with Schenker for three years in the mid 1920s and afterward explored analytical matters with him by correspondence, participated in the Schenker-Institut in Hamburg, from 1931 to 1933; and he reopened it in 1947 as the Heinrich-Schenker-Akademie. Schenker's pupil Oswald Jonas also taught two who would become active in writing and teach-

4 The Lexikon included the following Schenker students: Carl [Karl] Bamberger, Paul Breisach, Oswald Jonas, Maria Komorn, Grete Kraus, Felix Salzer, Georg Schenker, and Victor Zuckerkandl (in the 1941 Nachtrag); Jonas's student Ernst Oster was also listed.

5 The full description is as follows: "Hauptvertreter der abstrakten Musiktheorie der jüdischen Philosophie, die einen seelischen Inhalt im Tonwerk ableugnet und sich darauf beschränkt, durch willkürliche Kombination aus dem Zusammenhang einzelner Sonatensätze Tonreihen zu bilden, aus denen eine 'Urlinie' ('Substanzgemeinschaft') gelesen wird. Sch [enker]s Grundbegriffe waren weit verbreitet; mathematische Spielereien der voraussetzungslosen Musikästhetik der Nachkriegsjahre kamen dieser Theorie entgegen."

6 Bernhard Martin, Untersuchungen zur Struktur der Kunst der Fuge J.S. Bachs (Regensburg, Germany: Gustav Bosse, 1941); the book originated in the author's Ph.D. thesis (Univ. of Cologne, 1940), and also resulted in a related article, "J.S. Bachs letzte Fuge," Die Musik 33 (1940-41): 409-12. In the 1941 book, Schenker's writings are not cited in the bibliography, yet Martin's analytic methodology is clearly indebted to Schenker-even certain terminology is related but concealed through alteration. In its "Einleitung," Schenker is mentioned only to insult his work (see p. 14). See also a subsequent article by Martin, where again quasi-Schenkerian techniques are employed without due credit: "Mozart's Fuge 'Cum sancto spiritu' aus der grossen c-moll-Messe," Die Musik 34 (1941-42): $130-34$. 
ing about Schenker from around the middle of the century: Hellmut Federhofer (b. 1911) studied with Jonas in 1935-36 and was eventually appointed director of the musicology institute at Mainz University; and Franz Eibner (1914-86) studied with Jonas around the same time, and in the early 1950s began teaching Schenker at Vienna's Universität für Musik und darstellende Kunst, where in 1974 he established the Lehrgang für Tonsatz nach Heinrich Schenker. Karl-Otto Plum, who studied with von Cube in the 1960s, went on to complete what has been called "the first doctoral dissertation on Schenker to be received by a German university," ${ }^{\prime 7}$ Untersuchungen zu Heinrich Schenkers Stimmführungsanalyse (University of Cologne, 1978). And more recent years have witnessed an escalating interest in Schenker, as evidenced by recent conferences such as the Schenker-Traditionen Symposium, held in June 2003 at Vienna's Universität für Musik und darstellende Kunst; and a series of three conferences on Schenkerian analysis held in June 2004 in Berlin, Sauen, and Mannheim.

Nonetheless, it was in the US that Schenker's banner was lifted the highest in the decades following his death, and it is to activities in the US that I now turn.

\section{Early Advocates}

The dissemination of Schenkerian ideas in the US has a complex history, consisting not only of the recognized main lines of activity but also of various (and sometimes littleknown) individuals branching off from these lines in unexpected places, and still others appearing and working without clear connections to a main line. For present purposes, however, my survey of the early individuals who promoted Schenker in the US will be divided into the principal disciple-émigrés, and a few of the Americans who independently learned of Schenker.

The first of Schenker's students to come to the US was Hans Weisse (1892-1940), who had studied with Schenker since at least the beginning of 1912. In the fall of 1931, he began teaching in New York City at the David Mannes Music School (now Mannes College of Music). Starting the next year, he also conducted graduate seminars at Columbia University. Weisse's endeavors continued until his premature death in 1940. ${ }^{8}$ Shortly before this time, due to the Austro-German upheavals mentioned above, other Schenker students came to the US, including Felix Salzer and Oswald Jonas.

Salzer (1904-86) had been Weisse's own student until the latter departed for New York; at that time he began studying with Schenker himself. In 1940, Salzer assumed Weisse's duties at Mannes; he became director of the school in 1948, and stayed until 1956 (returning in 1962-64). He also taught for a decade (1963-74) at Queens College of the City University of New York. His long and productive career in the US included work as author and editor. His most influential writing was Structural Hearing (1952), which

7 William Drabkin, [Review of Karl-Otto Plum, Untersuchungen zu Heinrich Schenkers Stimmführungsanalyse, and Hellmut Federhofer, Akkord und Stimmführung in den musiktheoretischen Systemen von Hugo Riemann, Ernst Kurth und Heinrich Schenker], Music Analysis 2/1 (1983), 102.

8 For more on Weisse's career and his impact on Schenkerian dissemination in the US, see Berry 2003. 
had an impact on Schenkerian pedagogy in the US that was both considerable and-due to its revisions to and extensions of Schenker's own ideas-controversial.

Oswald Jonas (1897-1978), who began his studies with Schenker in 1915, emigrated in 1938 and taught at Roosevelt University (Chicago) from 1941 until 1964; and at the University of California, Riverside, from 1965 until his death in 1978. ${ }^{9}$ Jonas was especially interested in the field of sketch studies (as was Schenker), and several of his articles were not "Schenkerian" in an overtly analytical sense. He also edited a number of Schenker's writings for republication in German (e.g., the three volumes of his Neue musikalische Theorien und Phantasien). ${ }^{10}$ Around the same time he was responsible for editing the first of Schenker's books to be published in an English translation: Harmonielehre (1906), translated by Elisabeth Mann Borgese as Harmony (1954). It included an "Introduction" by Jonas in which Schenker's later ideas, such as the Ursatz, were explained. ${ }^{11}$

Other Schenker pupils came to the US and played lesser roles in disseminating his concepts. For example, Victor Zuckerkandl (1896-1965) incorporated some of Schenker's ideas into his class lectures at the New School of Social Research (New York City) and St. John's College (Annapolis, Maryland). ${ }^{12}$ Much more notable, however, was Ernst Oster (1908-77). Although sometimes grouped with the "first generation" of Schenker students, Oster studied not with Schenker but with Jonas in the early 1930s, at Berlin's Stern Conservatory. Following his emigration around 1939, he had more difficulties than the others in obtaining an institutional appointment. After teaching privately for many years, in the last decade of his life he taught at the New England Conservatory (Boston) and Mannes College of Music, ${ }^{13}$ and thus greatly increased the number of students with whom he was able to have contact. Oster published five essays in English, spanning the years 1947-66, but he is especially known for his translation and editing of Der Freie Satz as Free Composition (1979). ${ }^{14}$

These individuals taught many Americans who would go on to promulgate Schenkerian ideas in the ensuing decades. Creating a "family tree" of these studies can be complicated, as some people studied with more than one teacher; and in these cases, a person

9 In between his time at these two schools, in 1964/65, Jonas returned to his birth city to teach at the Vienna Music Academy.

10 Harmonielehre (Stuttgart: Cotta, 1906), second edition, edited by Oswald Jonas (Vienna: Universal, 1950); Kontrapunkt, Book I (Stuttgart: Cotta, 1910) and Book II (Vienna: Universal, 1922), second edition, edited by Oswald Jonas (Vienna: Universal, 1950); and Der Freie Satz (Vienna: Universal, 1935), second edition, edited and revised by Oswald Jonas (Vienna: Universal, 1956).

11 Jonas's Appendix II (pp. 349-52), which is an extension of the Introduction, uses J.S. Bach's Little Prelude in F (BWV 927) to demonstrate "the effects of Ursatz and stratification on a whole piece of composition" (xxiv). It is based on Jonas's earlier analytic essay, "Ein Bach-Präludium: Ein Weg zum organischen Hören," Der Dreiklang 1 (1937): 13-17.

12 Some of these materials eventually found their way into Zuckerkandl's book, The Sense of Music (Princeton, NJ: Princeton Univ. Press, 1959; corrected edition, 1971).

13 Oster also taught for a year at Princeton University.

14 It should be noted that a prior translation and editing had been completed by Theodore Krueger for his Ph.D. dissertation (State University of Iowa [now University of lowa], 1960), but it was not commercially published and circulated in relatively small numbers. 
might have taken formal lessons from one, but learned more informally from another. Furthermore, even the same two (or more) teachers could influence their mutual students in different degrees (perhaps especially if the students had the teachers in a different sequence). With these disclaimers in mind, a few of the connections can be named. Among others, Weisse taught Adele T. Katz and William J. Mitchell; Salzer taught Saul Novack and Carl Schachter; and Oster taught David Beach, John Rothgeb, and William Rothstein. Jonas taught fewer Americans who would become primarily known as Schenkerian scholars, although Rothgeb studied informally with him, having been referred by Oster. The expatriate group also had indirect connections with other prominent American Schenkerians; e.g., Allen Forte first learned of Schenker from Alvin Bauman, who had studied with Weisse. Illustrating the multiple associations mentioned above, Beach and Rothgeb first studied Schenker with Forte, before being referred to Oster; Rothstein, on the other hand, did it the other way around, moving to Yale and Forte after the New England Conservatory and Oster.

Although the Austro-German expatriates were of inarguable importance in disseminating Schenker's ideas, American musicians also came to Schenker in other ways during the early years. For example, Arthur Waldeck, a private voice and music-theory instructor in Brooklyn, New York, began corresponding with Schenker in 1929, and even proposed translating Harmonielehre in 1932. In 1935, with co-author Nathan Broder, Waldeck issued an early essay on Schenker's theories. George A. Wedge, a well-known theory pedagogue and teacher at New York's Institute of Musical Art (a precursor to the present-day Juilliard School), already knew of Schenker's work and apparently discussed it with his students prior to Weisse's arrival in the US. Indeed, Wedge's interest prompted him to arrange a meeting with Weisse soon after the latter arrived in $1931 .{ }^{15}$ Especially notable was composer and teacher Roger Sessions, who first encountered Schenker's work around 1926, while living in Europe. (His friend and neighbor in Florence, Italy, was the artist Victor Hammer, an associate and advocate of Schenker.) After returning to the US, Sessions wrote about Schenker in three articles (at times negatively); see Sessions 1935, 1938a, and 1938b. During this period he also taught Milton Babbitt, subsequently eminent as a composer and twelve-tone theorist. Schenkerian analysis was included in Babbitt's lessons from the very first one, during which the first movement of Beethoven's Piano Sonata in F Minor, op. 2/1, was discussed with reference to Schenker's analysis in Der Tonwille. ${ }^{16}$ (More on Sessions and Babbitt will follow.)

Through the teaching and writing of the early exponents, Schenker's ideas began to find a foothold in American music pedagogy and scholarship. However, a strengthened foundation would require the kinds of support to be surveyed in the following sections.

15 For more on Wedge and his Schenkerian influences, see Berry forthcoming-b.

16 See Schenker, "Beethoven: Sonate opus 2 Nr. 1," Der Tonwille 2 (1922): 25-48. Babbitt has said that one of the many reasons he had wanted to study with Sessions was the latter's writing about Schenker and, more generally, his demonstrated interest in analytical theory (Babbitt 1985:115). 


\section{Initial Institutional Homes}

The successful promotion of a new intellectual idea requires not only qualified individual advocates but supportive institutional homes. During its foundational decades in the US, Schenkerian theory established a presence at a few key institutions, beginning, of course, with Mannes. ${ }^{17}$ Indeed, Schenker's Fünf Urlinie-Tafeln (1932) was originally published with financial support from the Mannes School, for Weisse's classes. The emphasis on a Schenker-infused curriculum continued after Salzer began in 1940. His teaching there prompted his book Structural Hearing (1952). He also began the school's "Techniques of Music" program, which continues today with its integration of skills and Schenkerian analysis. Over the years, many other notable Schenkerians have taught at Mannes, some for longer periods (such as Carl Schachter, who joined the faculty in 1956 and became Dean of the College in 1962), and others for more brief periods (such as Mitchell, Forte, and Oster). ${ }^{18}$ Such involvement with the Mannes curriculum has resulted in two additional Schenker-influenced textbooks: Salzer's and Schachter's Counterpoint in Composition (1969), and Edward Aldwell's and Schachter's Harmony and Voice Leading (1979).

Mannes is still an important center for Schenkerian activities in the US. It has served as the meeting place for the International Schenker Symposia convened in 1985, 1992, and 1999 (with a fourth scheduled for 2006); and an "Institute on Schenkerian Theory and Analysis" was held in 2002 as part of the Mannes Institute for Advanced Studies in Music Theory. However, other schools would eventually gain ground in areas of advanced Schenkerian research, because (in the US) such work has flourished more at the graduate-and especially Ph.D.- - levels of universities than it has at conservatories. ${ }^{19}$ Indeed, it was the incorporation of Schenkerian theory into the curriculum of the university that marked a defining step in its acceptance in the US. This process proceeded slowly at first, with four schools playing early roles: Columbia, Princeton, Yale, and City University of New York.

The first university at which Schenkerian concepts had a measure of continuing support was Columbia, in New York City. As mentioned earlier, Weisse taught weekly graduate seminars there, from 1932 until his death in 1940. For the most part, these addressed "The Structure of Music" and apparently included Schenkerian elements. ${ }^{20}$ Weisse's time there overlapped with the presence of his former student, William J. Mitchell. After receiving a BA degree from Columbia in 1930, Mitchell had studied with Weisse in

17 There was an indirect connection between the school and Schenker before Weisse's time there: in the late 1920s, one of Mannes's piano teachers was Carl Bricken, an American-born composer who had studied piano in Vienna, with Weisse.

18 Schenker devotees who were there in capacities other than theory include Schenker's pupil Carl Bamberger, who began in 1938 and was a conductor and teacher of conducting; and Paul Berl, who had contributed a Schenkerian article to Der Dreiklang in 1937. Berl began at Mannes in 1948; he was a musical director in the opera department and a teacher of accompanying.

19 Mannes was not a degree-granting institution until 1953, when its bachelor's program began; it would take another three decades for its master's program to be launched.

20 He also taught composition and was one of the faculty members assigned to a seminar intended for the individual research needs of candidates for the Master of Arts degree. 
Vienna. Mitchell returned to Columbia in 1932, where he taught and earned an MA degree in 1938. The following year he published Elementary Harmony (1939), which was probably the first American undergraduate textbook to incorporate Schenkerian ideas (although it was not a Schenkerian text in a strict sense). Mitchell remained at Columbia until 1968, eventually becoming chair of the music department. In addition to his teaching, which incorporated Schenkerian methods, some of his articles were Schenkerian in focus, including a 1946 essay on Schenker's "approach to detail."

Two more of Weisse's American-born students were also active at Columbia. Alvin Bauman, who received his MA from Columbia in 1938 (and probably studied with Weisse around that time), taught there from 1945 to 1952. During that period he completed Elementary Musicianship (1947), a "text for beginning music courses" in which a few sections were clearly influenced by Schenkerian ideas. Bauman taught mainly during Columbia's summer sessions and in its School of General Studies (an adult- or continuing-education program); and in at least one of his summer courses-probably one in 1950 titled "Structure of Music" — he taught Schenkerian analysis. Adele T. Katz-who studied with Weisse in the early 1930s at Mannes, and whose 1935 article and 1945 book were among the early Schenkerian publications in English-taught from 1946 to 1951 at Teachers College, a graduate school of education affiliated with Columbia and adjacent to its campus. She conducted an evening course each term, titled "Analysis in Relation to Hearing and Performance." It was expressly described as a course on "The Schenker approach to the problems of musical structure," and likely exploited materials presented in her recently completed book. ${ }^{21}$

Although Columbia and Teachers College were not major centers of Schenkerian activity, in the way that the following schools would become, it is notable that a series of Schenker advocates was there over the years. ${ }^{22}$ Among the results was what is perhaps the first American doctoral dissertation to feature Schenker's theories prominently: Silberman 1949. ${ }^{23}$ Mitchell was a member of Silberman's dissertation committee, and later he was the adviser for another Columbia dissertation, this one with an exclusive focus on Schenker: Slatin 1967.

Roger Sessions (1896-1985) and Milton Babbitt (b. 1916) were named earlier. Both came to have long-term associations with Princeton University (roughly 55 miles to the southwest of New York City, in Princeton, New Jersey). Sessions began teaching there in 1936; afterward, Babbitt enrolled for graduate studies and in 1938 also joined the music faculty. (Both were subsequently active elsewhere but returned, Babbitt in 1948 and

21 For more on Katz's activities and writings, see Berry 2002.

22 Among this group was another supporter of the Schenkerian method (though probably not a Schenkerian analyst per se): Howard A. Murphy, who taught at Teachers College from 1927 to 1961. On the other hand, it should be noted that the Columbia music faculty included at least one ardent Schenker dissident: Paul Henry Lang.

23 Silberman's title, A Comparative Study of Four Theories of Chord Function, refers to the theories of Schenker, Hugo Riemann, Paul Hindemith, Joseph Schillinger; but it should be noted that Schenker's chapter was twice the length of those devoted to the other three. 
Sessions in 1953. $)^{24}$ Also influenced by Schenker were later Princeton faculty members who had initially been students there: Edward T. Cone (1917-2004), Godfrey Winham (1934-74), and Peter Westergaard (b. 1931). Cone had been a student of Sessions in the late 1930s and early 1940s, and had earned bachelors and masters degrees at Princeton; he began teaching there in 1947. His Schenkerian influences are suggested in such texts as Cone 1960, 1965, and 1968. Winham and Westergaard first studied music at Princeton in the 1950s. Winham stayed and completed his Ph.D. dissertation in 1964, and afterwards joined the faculty; Westergaard returned as a faculty member in 1968. Both were interested in Schenker: Winham published little, although he left extensive unpublished writings, including some about Schenker (for details of which see Blasius 1997); and Westergaard's tonal-music textbook (1975) was highly indebted to Schenker. With a faculty so inclined toward Schenker, the late 1960s saw the first of several Princeton doctoral dissertations to explore Schenkerian ideas, including Kassler 1967, Komar 1968, Morgan 1969, Boretz 1970, and Lester 1970. Given this context, it is no wonder that British composer Peter Maxwell Davies, who attended Princeton on a Harkness Fellowship in 1962-64, left convinced that "the Schoenberg-Schenker tradition" was one of the main influences on contemporary composers in the US (Davies 1965:3). Except at the schools cited in this section, one could hardly have arrived at such an elevated assessment of Schenker's influence in America at the time.

As Schenker began to bloom at Princeton, Allen Forte (b. 1926) was completing his masters degree at Columbia, where he had first learned of Schenker from Bauman. Forte spent the latter half of the 1950s teaching at Columbia University Teachers College and at Mannes. During this time he authored a book that adapted Schenkerian ideas to a study of twentieth-century music (Forte 1955), as well as two articles, one adapting a Schenkerian approach to show the interrelatedness of tempo, rhythm, and melody in Brahms's Haydn Variations (Forte 1957), the other offering an informed summary of Schenker's concepts (Forte 1959)..$^{25}$ In the fall of 1959, he began an appointment at Yale University (roughly 75 miles to the northeast of New York City, in New Haven, Connecticut) that would last 45 years. During his first semester there, he initiated a graduate seminar on Schenker at the School of Music. In the mid 1960s he moved to Yale's Department of Music and helped spearhead the doctoral degree program in music theory. Accordingly, the 1970s saw the first of many Yale doctoral dissertations to explore Schenkerian concepts, including Yeston 1974, Bashour 1975, and Baker 1977. ${ }^{26}$

24 Sessions taught at the University of California, Berkeley, from 1945 to 1953; and Babbitt spent much of the 1940s either working in mathematics or composing.

25 By early 1959, Forte had also completed a rough-draft translation of Der Freie Satz; however, he was unable to find an interested publisher. In 1962 these materials were given to Oster, so that the latter could continue the task.

26 Forte was not Bashour's advisor, but the latter credited the former for introducing Schenker's ideas to him and helping in the development of the dissertation's "analytical attitudes" (pp. iv-v). It should also be mentioned that the first of Forte's Ph.D. advisees to complete a dissertation was John Rothgeb, in 1968; however, despite the fact that Rothgeb later became an eminent Schenkerian, his dissertation involved Schenker only marginally. 
Finally there is the City University of New York (CUNY), a survey of which can be complicated as it consists of a number of colleges and schools. For present purposes, I will focus on two, beginning with Queens College (named after the borough of New York City in which it is located). The presence of Schenker at Queens was felt relatively early, due to the influence of Salzer's student Saul Novack (1918-98), who joined the faculty in 1952. Later, Salzer himself was a member of the faculty, as was another of his pupils, Carl Schachter. Among the Schenker-influenced masters theses submitted to Queens were Proctor 1968 and Porter 1969. In subsequent years, the component of CUNY most significant in terms of advanced Schenkerian research was its doctorate-granting institute, the Graduate Center (located in Manhattan). Novack was one of the individuals responsible for establishing the doctoral program in music; Schachter was also active at the Graduate Center from 1976 until 1996. Among its early Schenkerian doctoral dissertations were Sabbeth 1976, Hager 1978, and Porter 1979. A more steady stream of Schenkerian dissertations began flowing from CUNY in the late 1980s and afterward.

It should be acknowledged that other teachers, also interested in Schenker's work, were active in other schools during the same period outlined above. Included among them are Carl Bricken, at the University of Chicago (and later at the University of Wisconsin at Madison); Hubert Kessler, at the University of Illinois (Urbana-Champaign); Victor Vaughn Lytle, at the Oberlin (Ohio) Conservatory; and George Wedge (mentioned briefly earlier), at the Institute of Musical Art (New York). ${ }^{27}$ However, none of these schools fostered Schenkerian studies to the extent of those previously discussed-especially Princeton, Yale, and CUNY. Many who graduated from these three institutions went on to become leading Schenkerians of the next generation, and helped establish Schenker programs at other schools in the 1970s and ' 80 s. $^{28}$

\section{Dissemination through Journals}

Just as institutional homes were important for nurturing the teaching and study of Schenkerian theory, so were receptive academic journals important for further circulating Schenkerian scholarship. For most of the 1930s-50s, Schenker-related articles were published wherever authors could place them. The only journal that seems to have been especially accepting of Schenkerian essays was Musicology, a short-lived publication that produced only eight issues between 1945 and 1949; but three of these included Schenkerian articles: Mitchell 1946, Oster 1947, and Oster 1949. The situation gradually changed in subsequent years, as journals expressly devoted to music-theoretic and -analytic matters began to emerge; as they did, Schenkerians found new and welcoming vessels for their research.

First among these publications was the Journal of Music Theory (JMT), founded at Yale in 1957. Its first article devoted to a Schenkerian topic was Forte 1959, which appeared

27 For more on Bricken and Wedge, see Berry forthcoming-b; for Lytle, see Berry forthcoming-c.

28 For example, David Beach (who studied with Forte at Yale, and later with Oster) became the first to teach Schenker in a systematic way at the Eastman School of Music, beginning in 1974. 
in that year's April issue. By the subsequent November issue (vol. 3/2), Forte had joined the Yale faculty and had been named to $J M T$ 's editorial committee. He became editor with vol. 4/2 (1960) and continued in that capacity through vol. 11/1 (1967). ${ }^{29}$ During his tenure, several articles of a Schenkerian nature appeared, including Travis 1959 and its polemical response, Oster 1960; Oster 1961; Mitchell 1962; an analysis symposium on Mozart's Menuetto in D, K. 355, that included Oster 1966; and Beach 1967. In the years that immediately followed, other Schenkerian articles appeared, including in further "analysis symposia," in which different analyses of the same piece were published together. ${ }^{30}$ It is difficult to calculate how many articles JMT has published, to date, that have been devoted at least in large part to Schenkerian issues, as such a tally rests on subjective assessments as to what constitutes a "Schenkerian article." But it is probably safe to say that the journal has issued at least seventy-five such articles over the years, making it quite important to the Schenker enterprise in the US.

After JMT, the next theory-centered journal to debut was Perspectives of New Music $(P N M)$, first published in the fall of 1962. Based at Princeton, it focused on issues germane to more recent music, and was initially sponsored by the Fromm Music Foundation, an organization dedicated to supporting contemporary music in the US. Although its focus naturally precluded articles of a traditional Schenkerian bent, the fact that Princeton was an institutional nurturer of Schenkerian theory perhaps made inevitable some degree of Schenkerian content. ${ }^{31}$ To cite a few examples from PNM 's early years: Schenker-influenced analyses of Schoenberg and Webern appeared in Travis 1966, mathematical models for "layered music-theoretic systems" were suggested in Regener 1967, and Schenkerian views of rhythm were considered in Westergaard 1962 and Boretz 1971.

In 1967, the first volume of Music Forum (MF) appeared. Founded and edited jointly by Felix Salzer and William J. Mitchell, MF was a book series published sporadically until its sixth volume was released in 1987, the year after Salzer's death. ${ }^{32}$ As the editors proclaimed in the inaugural volume, MF was to have "a definite and unifying point of view" traceable to Schenker's ideas (and their extensions). Although many of the articles in MF would address tonal music of the period studied by Schenker himself, the goal was also to publish the work of those "who recognize the more universal values that lie dormant in [Schenker's] ideas and are capable of providing valuable insights into earlier and later music" (viii). Whereas Schenker-influenced studies of twentieth-century or "post-tonal"

29 Forte was succeeded as editor by David Beach, who would also become well known as a Schenkerian, having studied with both Forte and Oster.

30 See, for example, the symposia on Schubert's Moments Musicaux, op. 94/1, with Rothgeb 1969 and Schachter 1968 and 1969; on Beethoven's Piano Sonata in C, op. 53, with Beach 1969; on Brahms's "Wie Melodien zieht es mir," op. 105/1, with Clarkson 1971 and Laufer 1971; on the first movement of Webern's Orchestral Pieces (1913), with Travis 1974; and on Debussy's Twelve Etudes, vol. 1, no. 4, with Benjamin 1978 and Gauldin 1978.

31 Indeed, even though PNM 's first editor, Arthur Berger (1912-2003), taught not at Princeton but at Brandeis University (in the Boston area), he too had a connection with American Schenkerism: Berger had learned of Schenker from Weisse, while auditing the latter's Columbia seminar in the early 1930 s.

32 The final volume was to have been in two parts, only the first of which was published in 1987; to date, the second part has not appeared. 
music had become relatively frequent following Salzer's Structural Hearing (1952), similar approaches to "pre-tonal" music had been nearly non-existent since Salzer's Sinn und Wesen der abendländischen Mehrstimmigkeit (1935), which was not widely available in the US. One of $M F^{\prime}$ 's legacies was changing that, as five such articles appeared in its initial two volumes: Bergquist 1967, Salzer 1967, Mitchell 1970, Novack 1970, and Schachter 1970.

The journal landscape was altered greatly in the 1970s, as several new theory-oriented publications debuted. These included Theory and Practice (1975), the journal of the Music Theory Society of New York State; the first two graduate-student produced theory journals, In Theory Only (1975) at the University of Michigan (Ann Arbor), and Indiana Theory Review (1977) at Indiana University (Bloomington); and Music Theory Spectrum (1979), the official organ of the recently founded Society for Music Theory. The last-named journal even opted for an oblong page format to better accommodate figures such as Schenkerian graphs. ${ }^{33}$ From this time onward, authors of Schenkerian articles had several viable publication venues.

\section{Conference Presentations}

Another important way of increasing interest in and knowledge about Schenker's ideas was through papers presented at professional conferences. Except for a few such papers that would appear in published proceedings, these naturally lacked the permanence and capacity for wide distribution of journal articles. But they did allow the kind of interaction between authors and audiences (even, at times, masters and neophytes) important for an emerging field. Before the 1930s, papers on music-theoretic topics would have found a home at relatively few conferences, with the notable exception of the Music Teachers National Association (MTNA), about which more later. Fortunately, a receptive organization emerged around the same time that Schenkerian theory was being introduced to the US. In 1934, the American Musicological Society (AMS) was founded, in part as an outgrowth of the New York Musicological Society (active 1930-34). For the next few decades, the meetings of the AMS and its various regional chapters provided venues for Schenkerian papers. Schenker's pupil Victor Zuckerkandl spoke at a New England chapter meeting of the AMS in February 1942, just over two years after arriving in the US; and Felix Salzer gave a paper at the national AMS meeting in December 1949 (abstracts were published as Zuckerkandl 1945 and Salzer 1950). These papers—like one by Weisse to be cited momentarily - each contrasted, in different ways, the conventional "vertical" approach to harmony with Schenker's more "horizontal" approach. Other presenters had different aims. Frank Knight Dale delivered a paper in February 1941, to a Southeastern chapter meeting of the AMS, on the Schenkerian conception of form (abstract published as Dale 1943). Dale had taught at Mannes while Weisse was there, and perhaps learned of Schenker at that time. On the other hand, Schenker was only one component of Hertha Schweiger's paper of October 1938, given at a Greater New York

33 The precise size is 8.75 inches $(22 \mathrm{~cm})$ left to right, and 7.5 inches $(19 \mathrm{~cm})$ top to bottom. 
chapter meeting of the AMS (abstract published as Schweiger 1940). Her main focus was the proper balance between theory and history that musicology needed to achieve.

Returning to the MTNA, two early presentations are notable. The earliest Schenkerian conference paper (of which I am aware) was delivered to the organization, by Hans Weisse, in December 1935; it was subsequently published as Weisse $1936 .{ }^{34}$ In December 1936, when the MTNA and the AMS came together for a joint meeting, a Schenker-influenced paper was given by Carl Bricken, who had studied piano with Weisse years before. Published as Bricken 1937, it never cited Schenker's work directly; but its indebtedness was clear in both its prose and its somewhat freely styled linear reductions. ${ }^{35}$ After a lengthy hiatus, the 1950s saw two additional MTNA entries: a February 1955 paper by Salzer on "Some Significant Changes in the Teaching of Theory and Analysis" (unpublished); and a February 1959 paper by Roy Travis with the same title as Travis 1959, and presumably similar to the published version. Salzer also returned in April 1973, to deliver a paper on "Schenkerian Thought: Its Application and Impact Today" (unpublished).

The above citations demonstrate that Schenkerian papers certainly found a place on conference programs in the early decades; however, such papers were relatively few and far between. Speakers found venues wherever possible, but-as had been the case with early journal articles - it could be difficult at a time in which no conferences were devoted specifically to theoretic and analytic issues. ${ }^{36}$ This would change greatly beginning in the 1970s. The first regional theory organization, the Music Theory Society of New York State, held its initial meeting in 1971 at the Eastman School of Music. The first Michigan Conference on Music Theory was convened at the University of Michigan (Ann Arbor) in 1975; subsequent meetings were held in 1977 and 1981. Two National Conferences on Music Theory were convened, the first in 1976 (Boston), in association with the American Society of University Composers; and the second in 1977 (Evanston, Illinois), in association with the College Music Society. They helped precipitate the founding of the Society for Music Theory, which held its first annual conferencetogether with that of the AMS - in 1978 (Minneapolis). The next year (1979), the Texas Society for Music Theory held its first meeting; and in the years that followed, a number of other regional theory societies were formed and began holding conferences. The numerous theory conferences convened since the 1970s have allowed a great wealth of Schenkerian papers to be shared with interested musicians.

\section{Summary}

Thus Schenkerian theory slowly established its roots in the US, from the work of the initial advocates of the 1930s and afterwards, and at the early institutional homes of the

34 I explore Weisse's essay in Berry 2003, pp. 124-32.

35 I explore Bricken's essay in Berry forthcoming-b.

36 Other conference-holding organizations that would have been amenable to "theory" papers include the College Music Society (founded 1957), and the American Society of University Composers (founded 1966; later renamed Society of Composers). 
1930s-70s; through articles in especially the theory journals of the late 1950s and afterwards, and papers delivered at especially the theory conferences of the 1970s and afterwards. The dawn of the 1980s may be interpreted as the beginning of a new phase of Schenkerian activity in the US, as the infrastructure for its dissemination was now fully in place. Its continued growth in the music-theory community was also furthered by key publications that occurred around this time. In 1979, Schenker's Der Freie Satz was published in an English translation by Ernst Oster, making it available for the first time to many anglophones. ${ }^{37}$ Then, in 1982, Schenkerian pedagogy benefited from the release of the popular textbook by Forte and Gilbert, as well as John Rothgeb's translation of Jonas 1934. Schenker-influenced undergraduate textbooks such as Aldwell and Schachter 1979 and Lester 1982 appeared. Even Walter Piston's enduring Harmony-long a target of Schenkerians opposed to its overly "verticalist" approach to its subject-admitted some limited Schenkerian influences in its 1978 revision by Mark DeVoto.

Eugene Narmour's well-known critique and refutation of certain Schenkerian principles, in Beyond Schenkerism (1977), arose in part because of the perceived hegemony the theory was exerting (hence the book's subtitle: "The Need for Alternatives in Music Analysis" [emphasis mine]). For American music analysis at large, the threat of Schenkerian dominance may have been exaggerated in 1977. But it seems clear that Schenkerian theory had reached some important milestones by the end of the 1970s, and it was to enter a full-fledged growth mode for most of the next two decades.

II.

I turn now to present-day activities in the US. Some undergraduate (i.e., bachelors degree) programs offer courses in Schenkerian analysis - by which is generally meant the concepts and graphing techniques developed during Schenker's last decade of work, culminating in Fünf Urlinie-Tafeln (1932) and Der Freie Satz (1935). However, at the undergraduate level, it is more common for Schenker's pedagogical influences (whatever they may be) to remain implicit; and indeed, an increasing number of undergraduate textbooks have been affected by his ideas in various ways (for citations of these, see Berry 2004, section I.g). Most often, students learn about Schenker at the graduate (i.e., masters or doctoral) levels of education. For those earning graduate degrees in music theory, their basic curriculum usually compels them to study some amount of Schenkerian analysis. For those who wish to engage in further studies, some institutions-especially those that offer a Ph.D. in theory - offer appropriate courses or seminars. The culmination of advanced work may be a doctoral dissertation on a Schenkerian topic (or otherwise involving Schenkerian analysis). These are relatively common; e.g., for just the five years preceding its publication (i.e., 1999-2003), Berry 2004 cites over fifty doctoral dissertations (that are at least significantly Schenkerian) that were submitted to American schools.

37 See n.14 for reference to another, much less circulated English translation. 
Scholars who pursue advanced levels of research will discover that the range of potential topics is now quite broad. Indeed, in attempting to compile a selective bibliography to exemplify this range, I found the sheer volume of writings to be daunting. In Berry 2004, the most comprehensive Schenkerian bibliography to date, I offered around 3600 entries (2200 principal, 1400 secondary) representing the work of approximately 1475 authors. It was organized topically: fifteen broad groupings encompassed seventy topical headings, many of which were divided and subdivided again, resulting in a total of 271 headings under which entries were collected. Given such an abundance of material, it was a challenging task to reduce it to the modest size desired for the present survey. I had to impose the following restrictions on the selection process. The topical headings would be limited to around two dozen, and some of these would be broader and more general than in Berry 2004. The number of citations under each heading would be limited to around ten. As the present bibliography is primarily intended to serve those outside of the US, articles in periodicals would be favored over other sources (as, in general, they are more easily obtained through interlibrary loan); academic-degree theses would be omitted altogether (as, in general, they are more difficult to obtain outside the country of origin). Further selection criteria would include more recent over older publications; limits to the numbers of entries by the same author under a specific topic; and so forth. In the interest of conciseness, other information given in Berry 2004 would also be eschewed, such as descriptive comments, cross-references, citations of translations, and so forth. Lastly, given that the present bibliography is primarily to reflect Schenkerian activities in the US, I would select only Englishlanguage entries; however, on occasion these would include sources published outside the US, by non-American scholars. In sum, what follows should not be considered an abridgment of Berry 2004, but rather a different bibliography_a "sampler" of Schenkerian scholarship. Those seeking a more detailed and comprehensive picture of Schenkerian literature should naturally consult Berry 2004 (in which roughly 14\% of the citations are in languages other than English).

\section{A Survey of Select Research Topics}

In the following, I offer comments about the kinds of entries gathered under each of the present bibliography's divisions.

Section I. Collected here are articles (as opposed to textbooks) related to Schenkerian instruction and pedagogy. Part A offers "Analysis Demonstrations and Methodologies." Among the "demonstrations" are detailed accounts of issues that arise during the interpretation of music, as in Beach 1989. (Note that author-date references will apply only to citations in the bibliographic division under discussion.) The "methodologies" provide rules or guidelines for analysis, as per the structural "indices" of Plum 1988 and the "strict use" of analytic notation of Larson 1996. Part B, "Pedagogy," offers more explicit discussions of an array of pedagogical matters, from incorporating Schenkerian theory into the undergraduate curriculum (Damschroder 1985, Rothgeb 1981) to providing a pedagogical view of Schenker's theory (Beach 1983). 
Section II. Collected here are texts devoted to prominent theoretic and analytic topics. Part A gathers some that address a variety of "Prolongational Issues," from an investigation into its very nature (Larson 1997); to syntactical explications (Keiler 1977, Smith 1981); to interpretive extensions that contemplate multiple hierarchies (Pearsall 1996) and overlapping prolongations (Wagner 1995). Part B collects some sources that canvass various attributes of "The Urlinie, Ursatz, and Züge." Among the topics are the Anstieg (Berry 1999); the often-problematic octave line (Neumeyer 1987.3, Beach 1988, et al.); and unconventional articulations of the Urlinie, as when it is in the bass (Wen 1999) or "submerged" in the middle (Schachter 1994). Also cited are "revisionist" texts that modify Schenker's own conceptions in various ways, such as by proposing an ascending Urlinie (Neumeyer 1987.1) or different types of two-part Urlinien (Neumeyer 1987.2).

Section III. Collected here are texts that provide Schenkerian interpretations of certain kinds of melodic and harmonic entities. Part A, "Regarding Note Types and Melodic Events," includes studies of topics such as the leading tone (Chew 1983), the consonant passing tone (Drabkin 1996), implied tones (Rothstein 1991), and cover tones [Decktöne] (Suurpää 2003). Part B is given to "Motivic Parallelisms (Hidden Repetitions)" —i.e., Schenker's verborgene Wiederholung. From the venerable Burkhart 1978 onward, various approaches to the subject are found here, including one that addresses how motivic considerations reveal an underlying tension between Schenkerian theory and practice (Cohn 1992). The sources under Part $C$ address a topic that affects both melodic and harmonic events: "Chromaticism and Mixture." Although some explorations are broader, these typically focus on chromaticism in specific works or as evidenced by certain composers.

Section IV. Collected here are texts that investigate temporal and rhythmic aspects of music. Part A, "Rhythmic Theory: General," offers a few broader studies, including Schachter's well-known essays (1976, 1980, and 1987). The sources under Part B address organization beyond the level of the measure, i.e., "Phrase Aspects and Hypermeter." Finally, Part C collects an assortment of "Other Rhythmic and Metric Considerations," ranging from rhythmic/metric displacement (Rothstein 1990, Smith 2001), to other kinds of rhythmic/metric conflicts (Kamien 1993, Willner 1998) including the hemiola (Willner 1991 and 1996).

Section V. Collected here are texts that address aspects of form. Part A contains essays of a broader or more general nature, such as those that investigate Schenker's conception of Formenlehre (Smith 1996) or compare and reconcile Schenkerian and traditional theories of form (Schmalfeldt 1991). Part B collects texts that focus on a specific and significant form type, the sonata, either by exploring its treatment by a particular composer, or by addressing certain sections or features of the form. Finally, Part $\mathrm{C}$ is devoted to "Multi-Component Coherence," i.e., the larger-scale integration of the "individual" components or sections of works such as song cycles, operas, symphonies, and piano cycles and sonatas.

Section VI. Collected here are texts that extend Schenkerian theories and methodologies to compositions of periods and types beyond those that Schenker himself privileged (and for which his theories were developed). Part A consists of "Approaches to Modal/ 
'Pre-Tonal' Music." Some of these interpret the selected music more in terms of what it has in common with tonal music (e.g., Novack 1983), while others develop more historically situated reductive techniques (e.g., Judd 1992). Part B features "Approaches to 'Chromatic Tonality' in the Nineteenth Century." Several of these address compositions that transcend a monotonal conception. Here the notion of "directional" or "progressive" tonality - the achieving of closure in one key after beginning in another-receives much attention, as in Korsyn 1996, Loeb 1990, and Nelson 1992. Other ways of explaining such works include a consideration of "tonal pairing," in which two keys simultaneously occupy the highest position in a tonal hierarchy (see Krebs 1996). A bitonal Ursatz is even considered in Krebs 1985. Part C consists of "Approaches to 'Post-Tonal' Music (of the Twentieth Century and Afterward)." These entries are especially preoccupied with debating various notions of "post-tonal" prolongation and voice-leading. Part D collects some "Approaches to Popular and Rock Music," in which the repertory ranges from American Tin Pan Alley to more recent British-American pop/rock. Here one will find entries that focus on reportorial attributes such as the design of song bridges (Larson 2003), the linear progressions and linear intervallic patterns exhibited by songs (Gilbert 1997), and features of Tin Pan Alley songs in general (Forte 1995). There are also some artist-based studies, ranging from those that expressly present analytic methodologies (Burns 2000) to those that explore specific features, such as The Beatles' use of blue notes (Wagner 2003) and Paul Simon's chromaticism (Everett 1997). Finally, Part E assembles "Approaches to Jazz." Some address the topic of jazz analysis more generally (e.g., Larson 1998), while others focus on such aspects as harmony (Martin 1988, Strunk 1979), linear intervallic patterns (Strunk 1996), and other melodic characteristics (e.g., Larson 2002, Strunk 1985).

Section VII. Collected here are texts that extend the usual Schenkerian boundaries, not (necessarily) by exploring new repertories (as encountered under Section VI), but rather by integrating different concepts and methodologies into the analytic venture. Some of these are synthetic or comparative studies, meaning that they either juxtapose Schenkerian and other analytic methods, so as to demonstrate what each can (and cannot) reveal about a given composition, or they employ different methods alongside Schenkerian ones, so as to achieve a more comprehensive view of a composition. Although Schenker's ideas and methods have been combined and contrasted with those of many other individuals, the Schenker-Schoenberg coalition has proven most popular by far; accordingly, it has been selected as the representative topic of Part A. Some of these studies combine Ursatz and Grundgestalt, or other characteristic features; other studies address underlying conceptual differences between the two theorists (e.g., Borio 2001, Montgomery 1994, van den Toorn 1996). Part B features another popular approach: the integration of Schenkerian analysis and concepts drawn from literary or narrative theory, or (more generally) the combination of Schenkerian and dramatic or narrative interpretations. The ideas of Roland Barthes are considered in some; for example, one will find investigations of Barthes's narrative codes and their implications for tonal music (McCreless 1988), and of the parallels between literary and musical closure (McCreless 1991). Other studies are influenced by dramatists, such as Mar- 
tin 1987, which addresses relations between Bernard Grebanier's theory of playwriting and Schenker's theory of music. Instead of taking the work of a literary theorist (or other such figure) as a point of departure, some essays utilize Schenkerian analysis in order to demonstrate such features as connections between tonal structure and dramatic narratives in opera (Schachter 1991) or the plot-implicative programmatic aspects of nontexted music (Suurpää 1997).

Section VIII. Collected here are two applications of Schenkerian methodologies that are similar in that each moves beyond the printed score to engage issues germane to a work's creation or its realization by performers. Part A assembles "Sketch and Manuscript Studies" - a topic that was of great interest to Schenker (and notably also to his student Oswald Jonas). In the selections given here, authors engage in Schenkerian speculation for a variety of reasons: to explore the genesis and evolution of a work, to consider the hypothetical rationale for changes between earlier versions and the final one, to find what the materials reveal about compositional technique, and to support analytical interpretations. Most of the entries consider the ramifications of sketches and manuscripts for particular works, but some have broader goals; e.g., Rothgeb 1990 describes, with analytical illustrations, Schenker's and Jonas's views of the significance of composers' manuscripts. The focus of Part B is on issues related to "Performance Practice." Some entries utilize Schenkerian insights to inform and enhance performance; others consider the relationship between analysis and performance more generally. Among the contributions is Cook 1995, which offers an analysis of performance timings in recordings by conductor Wilhelm Furtwängler, a Schenker protégé and advocate; the analysis then facilitates an evaluation of parallels between Schenkerian analysis and performance interpretation.

Section IX. Finally, collected here are texts that situate Schenkerian theory and analysis within broader intellectual contexts. The "Philosophical Investigations" of Part A explore some of the foundations of Schenker's work. Some associate Schenker's ideas with those of Johann Wolfgang von Goethe, or consider the influence of Goethean archetypes and morphology on Schenker. Another topic is Schenker's organicism-including a study of his early rejection of the concept (Pastille 1984). Yet other entries focus on Schenker's value judgments (Pastille 1995), his theory and analytic practice in terms of ethics (Cook 1989), and so forth. Under Part B are explorations of Schenker's writings in terms of their "Conceptual and Ideological Backgrounds." Some entries explore contexts specific to Schenker's life; for example, Schachter 2001 places Schenker's political views in historical context, and Alpern 1999 considers the impact of Schenker's law training upon his musical development. Others concentrate on aspects of Schenker's work, such as his use of linguistic expressions keyed to the physical experience of body movement and orientation (Saslaw 1997-98), the different senses of "concealment" evoked in his essays (Snarrenberg 1992), and his "anti-historicism" (Cook 1993).

In sum, the following bibliographic sampler demonstrates that English-language Schenkerian studies are not only thriving, but are involved in a myriad of topics. For scholars entering the field today, there are innumerable subjects on which to focus their research and analyses. 
NB: For conciseness, in the following bibliography, books cited more than twice are designated by title and date only; their complete publication information is as follows:

Aspects of Schenkerian Theory (1983) = David W. Beach (ed.), Aspects of Schenkerian Theory (New Haven, CT: Yale Univ. Press, 1983)

The Practice of Performance (1995) = John S. Rink (ed.), The Practice of Performance:

Studies in Musical Interpretation (New York: Cambridge Univ. Press, 1995)

Schenker Studies (1990) = Hedi Siegel (ed.), Schenker Studies (New York: Cambridge Univ. Press, 1990)

Schenker Studies 2 (1999) = Carl Schachter and Hedi Siegel (eds.), Schenker Studies 2

(New York: Cambridge Univ. Press, 1999)

The Second Practice of Nineteenth-Century Tonality (1996) = William Kinderman and Harald Krebs (eds.), The Second Practice of Nineteenth-Century Tonality (Lincoln: Univ. of Nebraska Press, 1996)

Trends in Schenkerian Research (1990) = Allen Cadwallader (ed.), Trends in Schenkerian Research (New York: Schirmer, 1990)

\section{A Bibliographic Sampler}

I.

\section{A. Analysis Demonstrations and Methodologies}

David W. Beach, "The Analytic Process: A Practical Demonstration: The Opening Theme from Beethoven's Op. 26," Journal of Music Theory Pedagogy 3/1 (1989): 25-46.

Gene Biringer, "Teaching Schenkerian Analytic Notation: A New Synthesis of Pedagogical Approaches," Music Theory Explorations and Applications 4 (1995): 36-45.

William Drabkin, "A Lesson in Analysis from Heinrich Schenker: The C-Major Prelude from Bach's Well-Tempered Clavier, Book I," Music Analysis 4/3 (1985): 241-58.

Ann Hawkins, "Developing Criteria for Reduction Analysis," Theoretically Speaking: The Journal of the Florida State University Music Theory Society 6 (1989): 47-65.

Steve Larson, "The Strict Use of Analytic Notation," Journal of Music Theory Pedagogy 10 (1996): 37-77.

Karl-Otto Plum, "Towards a Methodology for Schenkerian Analysis," trans. William Drabkin, Music Analysis 7/2 (1988): 143-64.

Stephen Slottow, "Analytic Process in Schenkerian Pedagogy: An Introspective Exercise," Journal of Schenkerian Studies (forthcoming). 


\section{B. Pedagogy}

David W. Beach, "Schenker's Theories: A Pedagogical View," Aspects of Schenkerian Theory (1983): 1-38.

Allen Cadwallader and David Gagné, "The Spirit and Technique of Schenker Pedagogy," in L. Poundie Burstein and David Gagné (eds.), Structure and Meaning in Tonal Music: A Festschrift for Carl Schachter (Hillsdale, NY: Pendragon Press, forthcoming).

David Allen Damschroder, "Pedagogically Speaking: Structural Levels and the College Freshman," In Theory Only 8/6 (1985): 17-25.

David Gagné, "The Place of Schenkerian Analysis in Undergraduate and Graduate Curricula," Indiana Theory Review 15/1 (1994): 21-33.

Arthur J. Komar, "The Pedagogy of Tonal Hierarchy," In Theory Only 10/5 (1988): 2328.

Steve Larson, "Another Look at Schenker's Counterpoint," Indiana Theory Review 15/1 (1994): 35-53.

Herbert Lee Riggins and Gregory Proctor, "A Schenker Pedagogy," Journal of Music Theory Pedagogy 3/1 (1989): 1-24.

John Rothgeb, "Schenkerian Theory: Its Implications for the Undergraduate Curriculum," Music Theory Spectrum 3 (1981): 142-49.

William Rothstein, "Conservatory Schenker vs. University Schenker," Tijdschrift voor Muziektheorie 7/3 (2002): 239-41.

II.

\section{A. Prolongational Issues}

Karl Braunschweig, "Expanded Dissonance in the Music of J.S. Bach," Theory and Practice 28 (2003): 79-113.

Joseph Dubiel, "When You Are a Beethoven: Kinds of Rules in Schenker's Counterpoint," Journal of Music Theory 34/2 (1990): 291-340.

Yosef Goldenberg, "Negative Texture' and the Prolongation of Seventh Chords," Theory and Practice 29 (2004): 95-123.

Allan R. Keiler, "The Syntax of Prolongation (Part I)," In Theory Only 3/5 (1977): 3-27.

Steve Larson, "The Problem of Prolongation in Tonal Music: Terminology, Perception, and Expressive Meaning," Journal of Music Theory 41/1 (1997): 101-36.

Edward R. Pearsall, "Multiple Hierarchies: Another Perspective on Prolongation," Indiana Theory Review 17/1 (1996): 37-66.

Charles J. Smith, "Prolongations and Progressions as Musical Syntax," in Richmond Browne (ed.), Music Theory: Special Topics (New York: Academic Press, 1981): 139-74.

Naphtali Wagner, "No Crossing Branches? The Overlapping Technique in Schenkerian Analysis," Theory and Practice 20 (1995): 149-75. 


\section{B. The Urlinie, Ursatz, and Züge}

David W. Beach, "The Fundamental Line from Scale Degree 8: Criteria for Evaluation," Journal of Music Theory 32/2 (1988): 271-95.

David Carson Berry, "Dynamic Introductions: The Affective Role of Melodic Ascent and Other Linear Devices in Selected Song Verses of Irving Berlin," Intégral 13 (1999): 1-62.

Matthew Brown, "Rothstein's Paradox and Neumeyer's Fallacies," Intégral 12 (1998): 95-132. [NB: in part, the author considers the concept of an Ursatz and explains its nature and testability]

David Neumeyer, "The Ascending Urlinie," Journal of Music Theory 31/2 (1987): 275303.

—_, "The Three-Part Ursatz," In Theory Only 10/1-2 (1987): 3-29.

—, "The Urlinie from s:\{8\} as a Middleground Phenomenon," In Theory Only 9/5-6 (1987): 3-25.

William Pastille, "The Development of the Ursatz in Schenker's Published Works," Trends in Schenkerian Research (1990): 71-86.

Carl Schachter, "The Prelude from Bach's Suite No. 4 for Violoncello Solo: The Submerged Urlinie," Current Musicology 56 (1994): 54-71.

— , "Structure as Foreground: 'das Drama des Ursatzes," Schenker Studies 2 (1999): 298-314.

David H. Smyth, "Schenker's Octave Lines Reconsidered," Journal of Music Theory 43/1 (1999): 101-33.

Eric Wen, "Bass-line Articulations of the Urlinie," Schenker Studies 2 (1999): 276-97.

III.

\section{A. Regarding Note Types and Melodic Events}

Geoffrey Chew, "The Spice of Music: Towards a Theory of the Leading Note," Music Analysis 2/1 (1983): 35-53.

Nicholas Cook, "At the Borders of Musical Identity: Schenker, Corelli and the Graces," Music Analysis 18/2 (1999): 179-233.

William Drabkin, "Schenker, the Consonant Passing Note, and the First-Movement Theme of Beethoven's Sonata Op. 26," Music Analysis 15/2-3 (1996): 149-89.

David Gagné, "Unity in Diversity: The Retained Tone," in Allen Cadwallader (ed.) and Jan Miyake (assistant ed.), Essays from the Third International Schenker Symposium (Hillsdale, NY: Pendragon Press, forthcoming).

Arthur J. Komar, Theory of Suspensions: A Study of Metrical and Pitch Relations in Tonal Music (Princeton, NJ: Princeton Univ. Press, 1971).

William J. Renwick, "Schubert's Impromptu in G-Flat: A Response to Adam Krims," Canadian University Music Review 20/2 (2000): 31-41. [NB: the author reviews Schenker's 
ideas about the upper neighbor note; the titular impromptu is regarded as a test case for the neighbor's varied functions]

William Rothstein, "On Implied Tones," Music Analysis 10/3 (1991): 289-328.

Lauri Suurpää, "Cover Tone in Brahms's 'Immer leiser wird mein Schlummer' Op. 105, No. 2 and Mendelssohn's 'Lied ohne Worte' Op. 67, No. 1," in Mart Humal (ed.), A Composition as a Problem III (Tallinn, Estonia: Scripta Musicalia, 2003): 109-21.

Nicol Viljoen, "The Raised Fourth Degree of the Scale in Chopin's Mazurkas," Acta Academica 32/1 (2000): 67-85.

\section{B. Motivic Parallelisms (Hidden Repetitions)}

Brian Alegant and Donald McLean, "On the Nature of Enlargement," Journal of Music Theory 45/1 (2001): 31-71.

David W. Beach, "Motivic Repetition in Beethoven's Piano Sonata Op. 110: Part I: The First Movement," Intégral 1 (1987): 1-29; and "...Part II: The Trio of the Second Movement and the 'Adagio-Arioso,'" Intégral 2 (1988): 75-97.

Charles Burkhart, "Schenker's 'Motivic Parallelisms,'" Journal of Music Theory 22/2 (1978): 145-75.

Allen Cadwallader, "Motivic Unity and Integration of Structural Levels in Brahms's B-Minor Intermezzo, Op. 119, No. 1," Theory and Practice 8/2 (1983): 5-24.

- " "Prolegomena to a General Description of Motivic Relationships in Tonal Music," Intégral 2 (1988): 1-35.

— and William Pastille, "Schenker's High-Level Motives," Journal of Music Theory 36/1 (1992): 119-48.

Richard Cohn, "The Autonomy of Motives in Schenkerian Accounts of Tonal Music," Music Theory Spectrum 14/2 (1992): 150-70.

Roger Kamien, "Aspects of Motivic Elaboration in the Opening Movement of Haydn's Piano Sonata in C-Sharp Minor," Aspects of Schenkerian Theory (1983): 77-93.

John Rothgeb, "Thematic Content: A Schenkerian View," Aspects of Schenkerian Theory (1983): 39-60.

Christopher Wintle, "Skin and Bones': The C-Minor Prelude from J.S. Bach's Well-Tempered Clavier, Book 2," Music Analysis 5/1 (1986): 85-96.

\section{Chromaticism and Mixture}

David W. Beach, "Modal Mixture and Schubert's Harmonic Practice," Journal of Music Theory 42/1 (1998): 73-100.

David Carson Berry, "Gambling with Chromaticism? Extra-Diatonic Melodic Expression in the Songs of Irving Berlin," Theory and Practice 26 (2001): 21-85.

Matthew Brown, "The Diatonic and the Chromatic in Schenker's Theory of Harmonic Relations," Journal of Music Theory 30/1 (1986): 1-33. 
Roger Kamien, "Aspects of the Neapolitan Sixth Chord in Mozart's Music," Schenker Studies (1990): 94-106.

Joseph C. Kraus, "Mozart's Chromatic Third Relations: Evidence from the Late Quartets and Quintets," Journal of Musicological Research 9/4 (1990): 229-54.

Patrick McCreless, "Schenker and Chromatic Tonicization: A Reappraisal," Schenker Studies (1990): 125-45.

Richard S. Parks, "Voice Leading and Chromatic Harmony in the Music of Chopin," Journal of Music Theory 20/2 (1976): 189-214.

Carl Schachter, "Counterpoint and Chromaticism in Chopin's Mazurka in C-Sharp Minor, Opus 50, Number 3," Ostinato rigore: Revue internationale d'études musicales 15 (2000): 121-34.

Deborah Stein, "Schubert's 'Die Liebe hat gelogen': The Deception of Mode and Mixture," Journal of Musicological Research 9/2-3 (1989): 109-31.

Nicol Viljoen, "The Motivic, Structural, and Formal Implications of Mixture for Chopin's Mazurka Op. 30, No. 3," South African Journal of Musicology 11 (1991): 143-52.

Channan Willner, "Chromaticism and the Mediant in Four Late Haydn Works," Theory and Practice 13 (1988): 79-114.

IV.

A. Rhythmic Theory: General

Robert P. Morgan, "The Theory and Analysis of Tonal Rhythm," Musical Quarterly 64/4 (1978): 435-73.

Frank Samarotto, "Strange Dimensions: Regularity and Irregularity in Deep Levels of Rhythmic Reduction," Schenker Studies 2 (1999): 222-38.

Carl Schachter, "Rhythm and Linear Analysis: A Preliminary Study," Music Forum 4 (1976): 281-334.

—_, "Rhythm and Linear Analysis: Durational Reduction," Music Forum 5 (1980): 197232.

—, "Rhythm and Linear Analysis: Aspects of Meter," Music Forum 6/1 (1987): 1-60.

Maury Yeston, The Stratification of Musical Rhythm (New Haven, CT: Yale Univ. Press, 1976).

\section{B. Phrase Aspects and Hypermeter}

David W. Beach, "Phrase Expansion: Three Analytical Studies," Music Analysis 14/1 (1995): 27-47.

Mauro Botelho, "Meter and the Play of Ambiguity in the Third Brandenburg Concerto," In Theory Only 11/4 (1990): 1-35.

William Rothstein, Phrase Rhythm in Tonal Music (New York: Schirmer, 1989). 
Eric Wen, "Illusory Cadences and Apparent Tonics: The Effect of Motivic Enlargement upon Phrase Structures," Trends in Schenkerian Research (1990): 133-44.

Norman L. Wick, "Transformations of Middleground Hypermeasures in Selected Mozart Keyboard Sonatas," Theory and Practice 16 (1991): 79-102.

Channan Willner, "Sequential Expansion and Handelian Phrase Rhythm," Schenker Studies 2 (1999): 192-221.

\section{Other Rhythmic and Metric Considerations}

Howard Cinnamon, "Durational Reduction and Bach's C-Major Invention: An Alternative View," In Theory Only 7/4 (1983): 25-35.

- "New Observations on Voice Leading, Hemiola, and Their Roles in Tonal and Rhythmic Structures in Chopin's Prelude in B Minor, Op. 28, No. 6," Intégral 6 (1992): 66-106.

Gabe Fankhauser, "Rhythmic Dissonance as Motion Propellant in Brahms's Intermezzo in A-Flat Major," GAMUT: Journal of the Georgia Association of Music Theorists 8 (1998): 53-64.

Roger Kamien, "Conflicting Metrical Patterns in Accompaniment and Melody in Works by Mozart and Beethoven: A Preliminary Study," Journal of Music Theory 37/2 (1993): 311-48

Steve Larson, "On Analysis and Performance: The Contribution of Durational Reduction to the Performance of J.S. Bach's Two-Part Invention in C Major," In Theory Only 7/1 (1983): 31-45.

Patrick McCreless, "Schubert's Moment Musical No. 2: The Interaction of Rhythmic and Tonal Structures," In Theory Only 3/4 (1977): 3-11.

William Rothstein, "Rhythmic Displacement and Rhythmic Normalization," Trends in Schenkerian Research (1990): 87-114.

Peter H. Smith, "Brahms and the Shifting Barline: Metric Displacement and Formal Process in the Trios with Wind Instruments," in David Brodbeck (ed.), Brahms Studies 3 (Lincoln: Univ. of Nebraska Press, 2001): 191-229.

Channan Willner, "The Two-Length Bar Revisited: Handel and the Hemiola," Göttinger Händel-Beiträge 4 (1991): 208-31.

_ 2/3 (1996).

- "Stress and Counterstress: Accentual Conflict and Reconciliation in J.S. Bach's Instrumental Works," Music Theory Spectrum 20/2 (1998): 280-304. 
V.

\section{A. Form: General}

Allen Cadwallader, "Form and Tonal Process: The Design of Different Structural Levels," Trends in Schenkerian Research (1990): 1-22.

William Drabkin, "Chopin, Schenker, and 'Musical Form,'" Ostinato rigore: Revue internationale d'études musicales 15 (2000): 173-86.

Joel Galand, "Formenlehre Revived," Intégral 13 (1999): 143-200.

Eric McKee, "Auxiliary Progressions as a Source of Conflict between Tonal Structure and Phrase Structure," Music Theory Spectrum 18/1 (1996): 51-76.

Janet Schmalfeldt, "Towards a Reconciliation of Schenkerian Concepts with Traditional and Recent Theories of Form," Music Analysis 10/3 (1991): 233-87.

Charles J. Smith, "Musical Form and Fundamental Structure: An Investigation of Schenker's Formenlehre," Music Analysis 15/2-3 (1996): 191-297.

\section{B. Form: Specific Types: Sonata}

Jack Adrian, "The Ternary-Sonata Form," Journal of Music Theory 34/1 (1990): 57-80.

David W. Beach, "Schubert's Experiments with Sonata Form: Formal-Tonal Design versus Underlying Structure," Music Theory Spectrum 15/1 (1993): 1-18.

Timothy L. Jackson, "The Tragic Reversed Recapitulation in the German Classical Tradition," Journal of Music Theory 40/1 (1996): 61-111.

Deborah Kessler, "Motive and Motivation in Schubert's Three-Key Expositions," in L. Poundie Burstein and David Gagné (eds.), Structure and Meaning in Tonal Music: A Festschrift for Carl Schachter (Hillsdale, NY: Pendragon Press, forthcoming).

Edward Laufer, "Voice-Leading Procedures in Development Sections," Studies in Music from the University of Western Ontario 13 (1991): 69-120.

Gordon Sly, "Schubert's Innovations in Sonata Form: Compositional Logic and Structural Interpretation," Journal of Music Theory 45/1 (2001): 119-50.

Peter H. Smith, "Brahms and Schenker: A Mutual Response to Sonata Form," Music Theory Spectrum 16/1 (1994): 77-103.

David H. Smyth, "Balanced Interruption' and the Formal Repeat," Music Theory Spectrum 15/1 (1993): 76-88.

John L. Snyder, "Schenker and the First Movement of Mozart's Sonata K. 545: An Uninterrupted Sonata-Form Movement?," Theory and Practice 16 (1991): 51-78.

Lauri Suurpää, "Continuous Exposition and Tonal Structure in Three Late Haydn Works," Music Theory Spectrum 21/2 (1999): 174-99.

- " "The Undivided Ursatz and the Omission of the Tonic Stufe at the Beginning of the Recapitulation," Journal of Schenkerian Studies (forthcoming). 


\section{Form: Multi-Component Coherence}

V. Kofi Agawu, "Mahler's Tonal Strategies: A Study of the Song Cycles," Journal of Musicological Research 6/1 (1986): 1-47.

Walter Everett, "Grief in Winterreise: A Schenkerian Perspective," Music Analysis 9/2 (1990): 157-75.

Peter Kaminsky, "Principles of Formal Structure in Schumann's Early Piano Cycles," Music Theory Spectrum 11/2 (1989): 207-25.

Arthur J. Komar, "The Music of Dichterliebe: The Whole and the Parts," in Robert Schumann, Dichterliebe, ed. Arthur J. Komar, Norton Critical Scores series (New York: Norton, 1971): 63-94.

David Lawton, "Tonal Systems in Aida, Act III," in Carolyn Abbate and Roger Parker (eds.), Analyzing Opera (Berkeley: Univ. of California Press, 1989): 262-75.

David Neumeyer, "Organic Structure and the Song Cycle: Another Look at Schumann's Dichterliebe," Music Theory Spectrum 4 (1982): 92-105.

—, "Synthesis and Association, Structure and Design in Multi-Movement Compositions," in James M. Baker, David W. Beach, and Jonathan W. Bernard (eds.), Music Theory in Concept and Practice (Rochester, NY: Univ. of Rochester Press, 1997): 197-216.

George Parish, "Multi-Level Unification in Mozart's Piano Sonata, K. 333 (315c)," Mozart-Kongreß: Bericht über den internationalen Mozart-Kongreß, Salzburg 1991 (Kassel, Germany: Bärenreiter, 1992): vol. 2, pp. 1039-49.

Wayne C. Petty, "Cyclic Integration in Haydn's E-Flat Piano Sonata Hob. XVI:38," Theory and Practice 19 (1994): 31-55.

- "Brahms, Adolf Jensen and the Problem of the Multi-Movement Work," Music Analysis 22/1-2 (2003): 105-37.

VI.

\section{A. Approaches to Modal / "Pre-Tonal" Music}

Naomi Joy Barker, "In Search of Mannerism: A New Approach to an Old Problem," South African Journal of Musicology 12 (1992): 10-19.

Frederick Bashour, "Towards a More Rigorous Methodology for the Analysis of the PreTonal Repertory," College Music Symposium 19/2 (1978): 140-53.

Peter Bergquist, "Mode and Polyphony around 1500: Theory and Practice," Music Forum 1 (1967): 99-161.

Lori Burns, Bach's Modal Chorales (Stuyvesant, NY: Pendragon Press, 1995).

Sarah Fuller, "On Sonority in Fourteenth-Century Polyphony: Some Preliminary Reflections," Journal of Music Theory 30/1 (1986): 35-70.

Cristle Collins Judd, "Some Problems of Pre-Baroque Analysis: An Examination of Josquin's Ave Maria ... virgo serena," Music Analysis 4/3 (1985): 201-39. 
—, "Modal Types and 'Ut,' 'Re,' 'Mi' Tonalities: Tonal Coherence in Sacred Vocal Polyphony from about 1500," Journal of the American Musicological Society 45/3 (1992): 428-67.

Saul Novack, "The Analysis of Pre-Baroque Music," Aspects of Schenkerian Theory (1983): 113-33.

Dolores Pesce, "A Case for Coherent Pitch Organization in the Thirteenth-Century Double Motet," Music Analysis 9/3 (1990): 287-318.

Felix Salzer, "Tonality in Early Medieval Polyphony: Towards a History of Tonality," Music Forum 1 (1967): 35-98.

David Stern, "Schenkerian Theory and the Analysis of Renaissance Music," Schenker Studies (1990): 45-59.

\section{B. Approaches to "Chromatic Tonality" in the Nineteenth Century}

V. Kofi Agawu, "Extended Tonality in Mahler and Strauss," in Bryan Gilliam (ed.), Richard Strauss: New Perspectives on the Composer and His Work (Durham, NC: Duke Univ. Press, 1992): 55-75.

William E. Benjamin, "Tonal Dualism in Bruckner's Eighth Symphony," The Second Practice of Nineteenth-Century Tonality (1996): 237-58.

Kevin Korsyn, "Directional Tonality and Intertextuality: Brahms's Quintet Op. 88 and Chopin's Ballade Op. 38," The Second Practice of Nineteenth-Century Tonality (1996): 45-83.

Harald Krebs, "Alternatives to Monotonality in Early Nineteenth-Century Music," Journal of Music Theory 25/1 (1981): 1-16.

- "The Background Level in Some Tonally Deviating Works of Franz Schubert," In Theory Only 8/8 (1985): 5-18.

—, "Some Early Examples of Tonal Pairing: Schubert's 'Meeres Stille' and 'Der Wanderer,"' The Second Practice of Nineteenth-Century Tonality (1996): 17-33.

David Loeb, "Dual-Key Movements," Schenker Studies (1990): 76-83.

Patrick McCreless, "An Evolutionary Perspective on Nineteenth-Century Semitonal Relations," The Second Practice of Nineteenth-Century Tonality (1996): 87-113.

Robert P. Morgan, "Dissonant Prolongation: Theoretical and Compositional Precedents," Journal of Music Theory 20/1 (1976): 49-91.

John C. Nelson, "Progressive Tonality in the Finale of the Piano Quintet, Op. 44 of Robert Schumann," Indiana Theory Review 13/1 (1992): 41-51.

Carl Schachter, "Chopin's Fantasy Op. 49: The Two-Key Scheme," in Jim Samson (ed.), Chopin Studies (New York: Cambridge Univ. Press, 1988 [rpt. 1991]): 221-53.

Deborah Stein, Hugo Wolf's Lieder and Extensions of Tonality (Ann Arbor, MI: UMI Research Press, 1985). 


\section{Approaches to "Post-Tonal" Music (of the Twentieth Century and Afterward)}

James M. Baker, "Schenkerian Analysis and Post-Tonal Music," Aspects of Schenkerian Theory (1983): 153-86.

—, "Voice-Leading in Post-Tonal Music: Suggestions for Extending Schenker's Theory," Music Analysis 9/2 (1990): 177-200.

_- "Post-Tonal Voice-Leading," in Jonathan Dunsby (ed.), Models of Musical Analysis: Early Twentieth-Century Music (Oxford: Blackwell, 1993): 20-41.

Fred Lerdahl, "Atonal Prolongational Structure," Contemporary Music Review 4 (1989): 65-88.

- "Spatial and Psychoacoustic Factors in Atonal Prolongation," Current Musicology 63 (1999): 7-26.

Charles D. Morrison, "Prolongation in the Final Movement of Bartók's String Quartet No. 4," Music Theory Spectrum 13/2 (1991): 179-96.

Edward R. Pearsall, "Harmonic Progressions and Prolongation in Post-Tonal Music," Music Analysis 10/3 (1991): 345-55.

Joseph N. Straus, "The Problem of Prolongation in Post-Tonal Music," Journal of Music Theory 31/1 (1987): 1-21.

Olli Väisälä, "Concepts of Harmony and Prolongation in Schoenberg's Op. 19/2," Music Theory Spectrum 21/2 (1999): 230-59.

—, "Prolongation of Harmonies Related to the Harmonic Series in Early Post-Tonal Music," Journal of Music Theory 46/1-2 (2002): 207-83.

Paul Wilson, "Concepts of Prolongation and Bartók's Opus 20," Music Theory Spectrum 6 (1984): 79-89.

\section{Approaches to Popular and Rock Music}

David Carson Berry, "The Popular Songwriter as Composer: Mannerisms and Design in the Music of Jimmy Van Heusen," Indiana Theory Review 21 (2000): 1-51.

Lori Burns, "Analytic Methodologies for Rock Music: Harmonic and Voice-Leading Strategies in Tori Amos's 'Crucify,'" in Walter Everett (ed.), Expression in Pop-Rock Music: A Collection of Critical and Analytical Essays (New York: Garland, 2000): 213-46.

Walter Everett, "Voice Leading and Harmony as Expressive Devices in Early Music of The Beatles: 'She Loves You,'" College Music Symposium 32 (1992): 19-37.

—, "Swallowed by a Song: Paul Simon's Crisis of Chromaticism," in John Covach and Graeme M. Boone (eds.), Understanding Rock: Essays in Musical Analysis (New York: Oxford Univ. Press, 1997): 113-53.

- "The Learned vs. The Vernacular in the Songs of Billy Joel," Contemporary Music Review 18/4 (2000): 105-29.

Allen Forte, "Secrets of Melody: Line and Design in the Songs of Cole Porter," Musical Quarterly 77/4 (1993): 607-47. 
- The American Popular Ballad of the Golden Era: 1924-1950 (Princeton, NJ: Princeton Univ. Press, 1995).

Steven E. Gilbert, "Reflections on a Few Good Tunes: Linear Progressions and Intervallic Patterns in Popular Song and Jazz," in James M. Baker, David W. Beach, and Jonathan W. Bernard (eds.), Music Theory in Concept and Practice (Rochester, NY: Univ. of Rochester Press, 1997): 377-92.

Steve Larson, "What Makes a Good Bridge?," Tijdschrift voor Muziektheorie 8/1 (2003): $1-15$.

Naphtali Wagner, "Domestication' of Blue Notes in the Beatles' Songs," Music Theory Spectrum 25/2 (2003): 353-65.

\section{E. Approaches to Jazz}

Steve Larson, "Schenkerian Analysis of Modern Jazz: Questions about Method," Music Theory Spectrum 20/2 (1998): 209-41.

- "Swing and Motive in Three Performances by Oscar Peterson," Journal of Music Theory 43/2 (1999): 283-314.

- "Musical Forces, Melodic Expectation, and Jazz Melody," Music Perception 19/3 (2002): 351-85.

Henry Martin, "Jazz Harmony: A Syntactic Background," Annual Review of Jazz Studies 4 (1988): 9-30.

—, Charlie Parker and Thematic Improvisation (Lanham, MD: Institute of Jazz Studies [Rutgers Univ.] and Scarecrow Press, 1996).

Milton L. Stewart, "Structural Development in the Jazz Improvisational Technique of Clifford Brown," Jazzforschung/Jazz Research 6-7 (1975): 141-273.

Steven Strunk, "The Harmony of Early Bop: A Layered Approach," Journal of Jazz Studies 6/1 (1979): 4-53.

- "Bebop Melodic Lines: Tonal Characteristics," Annual Review of Jazz Studies 3 (1985): 97-120.

- "Linear Intervallic Patterns in Jazz Repertory," Annual Review of Jazz Studies 8 (1996): 63-115.

VII.

A. Synthetic (and Comparative) Studies: Schenker and Schoenberg

Gianmario Borio, "Schenker versus Schoenberg versus Schenker: The Difficulties of a Reconciliation," Journal of the Royal Musical Association 126/2 (2001): 250-74.

Jack F. Boss, "'Schenkerian-Schoenbergian Analysis' and Hidden Repetition in the Opening Movement of Beethoven's Piano Sonata Op. 10, No. 1," Music Theory Online 5/1 (1999). 
Howard Cinnamon, "Some Elements of Tonal and Motivic Structure in 'In diesen Wintertagen,' Op. 14, No. 2, by Arnold Schoenberg: A Schoenbergian-Schenkerian Study," In Theory Only 7/7-8 (1984): 23-49.

Michael Mathis, "Arnold Schoenberg's Grundgestalt and Gustav Mahler's 'Urlicht,'" International Journal of Musicology 5 (1996): 239-59.

Kip Montgomery, "Schenker and Schoenberg on Harmonic Tonality," Indiana Theory Review 15/1 (1994): 53-68.

Jairo Moreno, "Schenker's Parallelisms, Schoenberg's Motive, and Referential Motives: Notes on Pluralistic Analysis," College Music Symposium 41 (2001): 91-111.

Graham H. Phipps, "A Response to Schenker's Analysis of Chopin's Etude Opus 10, No. 12, Using Schoenberg's Grundgestalt Concept," Musical Quarterly 69/4 (1983): 543-69.

Pieter C. van den Toorn, "What's in a Motive? Schoenberg and Schenker Reconsidered," Journal of Musicology 14/3 (1996): 370-99.

Lawrence Whiffin, "Schenker versus Schoenberg-A Composer's Dilemma," in Brenton Broadstock et al. (eds.), Aflame with Music: 100 Years of Music at the University of Melbourne (Parkville, Victoria [Australia]: Centre for Studies in Australian Music, Univ. of Melbourne, 1996): 343-54.

\section{B. Synthetic Studies: Schenker and Drama, Narrative, and Literary Theory}

Ira Braus, "Poetic-Musical Rhetoric in Brahms's 'Auf dem Kirchhofe,' Op. 105, No. 4," Theory and Practice 13 (1988): 15-30.

Matthew Brown and Roger Parker, "Motivic and Tonal Interaction in Verdi's Un ballo in maschera," Journal of the American Musicological Society 36/2 (1983): 243-65.

Ted Conner, "Cherubino Rediscovered: Text, Music, and Narrative in Mozart's Trio," Theory and Practice 25 (2000): 27-64.

Stephen Downes, "Musical Pleasures and Amorous Passions: Stendhal, the Crystallization Process, and Listening to Rossini and Beethoven," 19th Century Music 26/3 (2003): 235-57.

John S. Ellis, "A Narrative Analysis of Schumann's Kinderszenen," in Eero Tarasti, Paul Forsell, and Richard Littlefield (eds.), Musical Semiotics Revisited (Imatra, Finland: Intl. Semiotics Institute, 2003): 303-19.

Henry Martin, "Syntax in Music and Drama," In Theory Only 10/1-2 (1987): 65-78.

Patrick McCreless, "Roland Barthes's S/Z from a Musical Point of View," In Theory Only 10/7 (1988): 1-29.

- "The Hermeneutic Sentence and Other Literary Models for Tonal Closure," Indiana Theory Review 12 (1991): 35-73.

David Neumeyer, "Tonal Design and Narrative in Film Music: Bernard Herrmann's A Portrait of Hitch and The Trouble with Harry," Indiana Theory Review 19/1-2 (1998): 87-123. 
Carl Schachter, "The Adventures of an F-Sharp: Tonal Narration and Exhortation in Donna Anna's First-Act Recitative and Aria," Theory and Practice 16 (1991): 5-20.

Lauri Suurpää, Music and Drama in Six Beethoven Overtures: Interaction between Programmatic Tensions and Tonal Structure, Studia musica series (Helsinki: Hakapaino Oy for the Sibelius Academy, 1997).

- "Programmatic Aspects of the Second Sonata of Haydn's Seven Last Words," Theory and Practice 24 (1999): 29-55.

VIII.

\section{A. Sketch and Manuscript Studies}

Kevin Bazzana, "The First Movement of Beethoven's Opus 109: Compositional Genesis and Structural Dialectic," Canadian University Music Review 12/1 (1992): 1-36.

Stephen E. Hefling, "The Composition of [Mahler's] 'Ich bin der Welt abhanden gekommen,'" in Hermann Danuser (ed.), Gustav Mahler (Darmstadt: Wissenschaftliche Buchgesellschaft, 1992): 96-158.

- "'Ihm in die Lieder zu blicken ': Mahler's Seventh Symphony Sketchbook," in Stephen E. Hefling (ed.), Mahler Studies (New York: Cambridge Univ. Press, 1997): 169-216.

Timothy L. Jackson, “Compositional Revisions in Strauss's 'Waldseligkeit' and a New Source," Richard Strauss-Blätter 21 (1989): 55-82.

- "The Metamorphosis of the Metamorphosen: New Analytical and Source-Critical Discoveries," in Bryan Gilliam (ed.), Richard Strauss: New Perspectives on the Composer and His Work (Durham, NC: Duke Univ. Press, 1992): 193-241.

Larry Laskowski, "Voice Leading and Meter: An Unusual Mozart Autograph," Trends in Schenkerian Research (1990): 41-50.

David Lawton, "A New Sketch for Verdi's I due Foscari," Verdi Newsletter 22 (1993): 4-16.

Nicholas Marston, "Schenker and Forte Reconsidered: Beethoven's Sketches for the Piano Sonata in E, Op. 109," 19th Century Music 10/1 (1986): 24-42.

John Rothgeb, "Schenkerian Theory and Manuscript Studies: Modes of Interaction," Schenker Studies (1990): 4-14.

Jim Samson, "The Composition-Draft of the Polonaise-Fantasy: The Issue of Tonality," in Jim Samson (ed.), Chopin Studies (New York: Cambridge Univ. Press, 1988 [rpt. 1991]): 41-58.

Carl Schachter, "The Prelude in E Minor Op. 28 No. 4: Autograph Sources and Interpretation," in John S. Rink and Jim Samson (eds.), Chopin Studies 2 (New York: Cambridge Univ. Press, 1994): 161-82.

- , "The Sketches for the Sonata for Piano and Violin, Op. 24 [by Beethoven]," in Christopher Reynolds (ed.-in-chief), and Lewis Lockwood and James Webster (eds.), Beethoven Forum 3 (1994): 107-25. 


\section{B. Performance Practice}

David W. Beach, "The First Movement of Mozart's Piano Sonata in A Minor, K. 310: Some Thoughts on Structure and Performance," Journal of Musicological Research 7/2-3 (1987): 157-79 (score appended, pp. 180-86).

Nicholas Cook, "The Conductor and the Theorist: Furtwängler, Schenker and the First Movement of Beethoven's Ninth Symphony," The Practice of Performance (1995): $105-25$

Cynthia Folio, "Analysis and Performance of the Flute Sonatas of J.S. Bach: A Sample Lesson Plan," Journal of Music Theory Pedagogy 5/2 (1991): 133-60.

Roger Kamien, "Analysis and Performance: Some Preliminary Observations," Israel Studies in Musicology 3 (1983): 156-70.

Joel Lester, "Performance and Analysis: Interaction and Interpretation," The Practice of Performance (1995): 197-216.

Deborah Mawer, "Bridging the Divide: Embedding Voice-Leading Analysis in String Pedagogy and Performance," British Journal of Music Education 16/2 (1999): 179-95.

Catherine Nolan, "Reflections on the Relationship of Analysis and Performance," College Music Symposium 33-34 (1993-94): 112-39.

William Rothstein, "Analysis and the Act of Performance," The Practice of Performance (1995): 217-40.

Carl Schachter, "Playing What the Composer Didn't Write," in Bruce Brubaker and Jane Gottlieb (eds.), Pianist, Scholar, Connoisseur: Essays in Honor of Jacob Lateiner (Stuyvesant, NY: Pendragon Press, 2000): 47-68.

—, "Taking Care of the Sense: A Schenkerian Pedagogy for Performers," Tijdschrift voor Muziektheorie 6/3 (2001): 159-70.

Janet Schmalfeldt, "On the Relation of Analysis to Performance: Beethoven's Bagatelles Op. 126, Nos. 2 and 5," Journal of Music Theory 29/1 (1985): 1-31.

Faun S. Tanenbaum, "The Sarabande of J.S. Bach's Suite No. 2 for Unaccompanied Violoncello, BWV 1008: Analysis and Interpretation," Theory and Practice 5/1 (1980): 40-56.

IX.

\section{A. Schenker's Writing: Philosophical Investigations}

Byron Almén, "Prophets of the Decline: The Worldviews of Heinrich Schenker and Oswald Spengler," Indiana Theory Review 17/1 (1996): 1-24.

Michael Cherlin, "Hauptmann and Schenker: Two Adaptations of Hegelian Dialectics," Theory and Practice 13 (1988): 115-31.

Nicholas Cook, "Schenker's Theory of Music as Ethics," Journal of Musicology 7/4 (1989): 415-39.

Gary W. Don, "Goethe and Schenker," In Theory Only 10/8 (1988): 1-14. 
Nadine Hubbs, "Schenker's Organicism," Theory and Practice 16 (1991): 143-62.

Jamie Croy Kassler, "Heinrich Schenker's Epistemology and Philosophy of Music: An Essay on the Relations between Evolutionary Theory and Music Theory," in D. Oldroyd and I. Langham (eds.), The Wider Domain of Evolutionary Thought (Dordrecht, The Netherlands: R. Reidel, 1983): 221-60.

Kevin Korsyn, "Schenker and Kantian Epistemology," Theoria 3 (1988): 1-58.

—, "Schenker's Organicism Reexamined," Intégral 7 (1993): 82-118.

William Pastille, "Heinrich Schenker: Anti-Organicist," 19th Century Music 8/1 (1984): 29-36.

- "Music and Morphology: Goethe's Influence on Schenker's Thought," Schenker Studies (1990): 29-44.

__, "Schenker's Value Judgments," Music Theory Online 1/6 (1995).

\section{B. Schenker's Writing: Conceptual and Ideological Backgrounds.}

Wayne Alpern, "Music Theory as a Mode of Law: The Case of Heinrich Schenker, Esq.," Cardozo Law Review 20/5-6 (1999): 1459-1511.

Leslie D. Blasius, Schenker's Argument and the Claims of Music Theory (New York: Cambridge Univ. Press, 1996).

Nicholas Cook, "Heinrich Schenker, Anti-Historicist," Revista de musicologia 16/1 (1993): 420-32 [24-36].

- "Heinrich Schenker, Modernist: Detail, Difference, and Analysis," Theory and Practice 24 (1999): 91-106.

Allan R. Keiler, "The Origins of Schenker's Thought: How Man is Musical," Journal of Music Theory 33/2 (1989): 273-98.

Robert P. Morgan, "Schenker and the Twentieth Century: A Modernist Perspective," in Andreas Giger and Thomas J. Mathiesen (eds.), Music in the Mirror: Reflections on the History of Music Theory and Literature for the Twenty-First Century (Lincoln: Univ. of Nebraska Press, 2002): 247-74.

Janna K. Saslaw, "Life Forces: Conceptual Structures in Schenker's Free Composition and Schoenberg's The Musical Idea," Theory and Practice 22-23 (1997-98): 17-33.

Carl Schachter, "Elephants, Crocodiles, and Beethoven: Schenker's Politics and the Pedagogy of Schenkerian Analysis," Theory and Practice 26 (2001): 1-20.

Robert Snarrenberg, "Schenker's Senses of Concealment," Theoria 6 (1992): 97-134.

—, Schenker's Interpretive Practice (New York: Cambridge Univ. Press, 1997). 


\section{References}

Aldwell, Edward and Carl Schachter. 1979. Harmony and Voice Leading. New York: Harcourt Brace Jovanovich. 3rd edn., Belmont, CA: Schirmer/Wadsworth Group/ Thomson Learning, 2003.

Babbitt, Milton. 1985. "I Remember Roger." Perspectives of New Music 23/2: 112-16.

Baker, James M. 1977. Alexander Scriabin: The Transition from Tonality to Atonality. Ph.D. thesis, Yale University.

Bashour, Frederick. 1975. A Model for the Analysis of Structural Levels and Tonal Movement of Compositions of the Fifteenth Century. Ph.D. thesis, Yale University.

Bauman, Alvin. 1947. Elementary Musicianship. New York: Prentice-Hall.

Beach, David W. 1967. "The Functions of the Six-Four Chord in Tonal Music." Journal of Music Theory 11/1: 2-31.

- 1969. "Analysis Symposium [on Beethoven, Piano Sonata in C, Op. 53 ('Waldstein,' 1803-04): Introduzione]." Journal of Music Theory 13/2: 188-203.

Benjamin, William E. 1978. "Analysis Symposium: Debussy, Etude 'pour les Sixtes' [Twelve Etudes, vol. 1, no. 4 (1915)]." Journal of Music Theory 22/2: 253-90.

Bergquist, Peter. 1967. "Mode and Polyphony around 1500: Theory and Practice," Music Forum 1: 99-161.

Berry, David Carson. 2002. "The Role of Adele T. Katz in the Early Expansion of the New York 'Schenker School.'" Current Musicology 74: 103-51.

_. 2003. "Hans Weisse and the Dawn of American Schenkerism." Journal of Musicology 20/1: 104-56.

—. 2004. A Topical Guide to Schenkerian Literature: An Annotated Bibliography with Indices. Hillsdale, NY: Pendragon Press.

—. Forthcoming-a. "Early Schenker Reception through English-Language Writings Prior to the Mid-1950s." Journal of Music Theory.

- Forthcoming-b. "Verborgene Wiederholungen? Schenker's (Hidden?) Influence in America before the Mannes Vanguard." Theory and Practice.

—. Forthcoming-c. "Victor Vaughn Lytle and the Early Proselytism of Schenkerian Ideas in the U.S." Journal of Schenkerian Studies.

Blasius, Leslie David. 1997. The Music Theory of Godfrey Winham. Princeton, NJ: Department of Music, Princeton University.

Boretz, Benjamin. 1970. Meta-Variations: Studies in the Foundations of Musical Thought. Ph.D. thesis, Princeton University.

—. 1971. "In Quest of the Rhythmic Genius." Perspectives of New Music 9/2-10/1: 149-55.

Bricken, Carl. 1937. "Some Analytical Approaches to Musical Criticism." Volume of Proceedings of the Music Teachers National Association [for the Meeting of Dec. 1936]: 262-68. 
Clarkson, Austin. 1971. "Analysis Symposium: Brahms Op. 105/1 ['Wie Melodien zieht es mir,' 1886]." Journal of Music Theory 15/1-2: 2-57.

Cone, Edward T. 1960. "Analysis Today." Musical Quarterly 46/2: 172-88.

—. 1965. "On the Structure of 'Ich folge dir.'" College Music Symposium 5: 77-87.

- 1968. Musical Form and Musical Performance. New York: Norton.

Dale, Frank Knight. 1943. "Heinrich Schenker and Musical Form." Bulletin of the American Musicological Society 7: 12-13. Reprinted in Theory and Practice 10/1-2 (1985): 23.

Davies, Peter Maxwell. 1965. "The Young Composer in America." Tempo 72: 2-6. Reprinted from The American Scholar 33/4 (1964): 620-28 [even pages only].

Forte, Allen. 1955. Contemporary Tone-Structures. New York: Bureau of Publications, Columbia University Teachers College.

—. 1959. "Schenker's Conception of Musical Structure." Journal of Music Theory 3/1: $1-30$.

— and Steven E. Gilbert. 1982. Introduction to Schenkerian Analysis: Form and Content in Tonal Music. New York: Norton.

Gauldin, Robert. 1978. "Analysis Symposium: Debussy, Etude 'pour les Sixtes' [Twelve Etudes, vol. 1, no. 4 (1915)]." Journal of Music Theory 22/2: 241-51.

Hager, Nancy Barnes. 1978. Rhythm and Voice-Leading as a Facet of Style: Keyboard Works of J.S. Bach, C.P.E. Bach, and Mozart. Ph.D. thesis, City University of New York.

Hinton, Stephen. 1998. "Die Musiktheorie Heinrich Schenkers und ihre Übertragung ins Englische." In Musik als Text, ed. by Hermann Danuser and Tobias Plebuch. Kassel, Germany: Bärenreiter, vol. 1, 185-89.

Jonas, Oswald. 1934. Das Wesen des musikalischen Kunstwerks: Eine Einführung in die Lehre Heinrich Schenkers. Vienna: Saturn-Verlag. Also 2nd edn., Vienna: Universal, 1972. Translated and ed. by John Rothgeb as Introduction to the Theory of Heinrich Schenker: The Nature of the Musical Work of Art (New York: Longman, 1982).

Kassler, Michael. 1967. A Trinity of Essays: Toward a Theory That is the Twelve-Note Class System, Toward Development of a Constructive Tonality Theory Based on Writings by Heinrich Schenker, Toward a Simple Programming Language for Musical Information Retrieval. Ph.D. thesis, Princeton University.

Katz, Adele T. 1945. Challenge to Musical Tradition: A New Concept of Tonality. New York: Knopf.

Komar, Arthur J. 1968. Theory of Suspensions. Ph.D. thesis, Princeton University.

Krueger, Theodore Howard. 1960. Der Freie Satz by Heinrich Schenker: A Complete Translation and Re-Editing. Ph.D. thesis, State University of Iowa (now University of lowa).

Laufer, Edward. 1971. "Analysis Symposium: Brahms Op. 105/1 ['Wie Melodien zieht es mir,' 1886]." Journal of Music Theory 15/1-2: 34-57. 
Lester, Joel. 1970. A Theory of Atonal Prolongations, as Used in an Analysis of the Serenade, Op. 24, by Arnold Schoenberg. Ph.D. thesis, Princeton University.

- 1982. Harmony in Tonal Music. New York: Knopf.

Mitchell, William J. 1939. Elementary Harmony. New York: Prentice-Hall.

—. 1946. "Heinrich Schenker's Approach to Detail." Musicology 1/2: 117-28.

—. 1962. "The Study of Chromaticism." Journal of Music Theory 6/1: 2-31.

- 1970. "The Prologue to Orlando di Lasso's Prophetiae Sibyllarum." Music Forum 2: $264-73$.

Morgan, Robert P. 1969. The Delayed Structural Downbeat and Its Effect on the Tonal and Rhythmic Structure of Sonata Form Recapitulation. Ph.D. thesis, Princeton University.

Narmour, Eugene. 1977. Beyond Schenkerism: The Need for Alternatives in Music Analysis. Chicago: University of Chicago Press.

Novack, Saul. 1970. "Fusion of Design and Tonal Order in Mass and Motet: Josquin Desprez and Heinrich Isaac." Music Forum 2: 187-263.

Oster, Ernst. 1947. "The Fantasie-Impromptu: A Tribute to Beethoven." Musicology 1/4: 407-29.

— 1949. "The Dramatic Character of the Egmont Overture." Musicology 2/3: 26985.

—. 1960. "Re: A New Concept of Tonality (?)." Journal of Music Theory 4/1: 85-101

- 1961. "Register and the Large-Scale Connection." Journal of Music Theory 5/1: 54-71.

—. 1966. "Analysis Symposium [on Mozart, Menuetto in D for Piano, K. 355 (?178687)]." Journal of Music Theory 10/1: 32-52.

Piston, Walter. 1978. Harmony. 4th edn., rev. and expanded by Mark DeVoto. New York: Norton.

Porter, Steven. 1969. Concepts of Development in the String Quartets of Joseph Haydn: A Comparative Study of the Sonata-Allegro First Movements of Opus 20 with Those of Opus 76. M.A. thesis, Queens College, City University of New York.

- 1979. Rhythm and Harmony in the Music of The Beatles. Ph.D. thesis, City University of New York, 1979.

Proctor, Gregory. 1968. Schoenberg's Opus 11, No. 1 and Opus 19: A Structural Analysis. M.A. thesis, Queens College, City University of New York.

Regener, Eric. 1967. "Layered Music-Theoretic Systems." Perspectives of New Music 6/1: 52-62.

Rothgeb, John. 1969. "Another View on Schubert's Moment Musical, Op. 94/1." Journal of Music Theory 13/1: 128-39.

Rothstein, William. 1990. "The Americanization of Heinrich Schenker." In Schenker Studies, ed. Hedi Siegel. New York: Cambridge University Press, 193-203. 
—. 2002. "Conservatory Schenker vs. University Schenker." Tijdschrift voor Muziektheorie 7/3: 239-41.

Sabbeth, Daniel Paul. 1976. Principles of Tonal and Dramatic Organization in Verdi's Falstaff. Ph.D. thesis, City University of New York.

Salzer, Felix. 1935. Sinn und Wesen der abendländischen Mehrstimmigkeit. Vienna: Saturn-Verlag.

- 1950. "Directed Motion-The Basic Factor of Musical Coherence." Journal of the American Musicological Society 3/2: 157.

—. 1952. Structural Hearing: Tonal Coherence in Music. New York: Charles Boni.

—. 1967. "Tonality in Early Medieval Polyphony: Towards a History of Tonality." Music Forum 1: 35-98.

— and Carl Schachter. 1969. Counterpoint in Composition: The Study of Voice Leading. New York: McGraw-Hill. Reprinted New York: Columbia Univ. Press, 1989.

Schachter, Carl. 1968. "Analysis Symposium [on Schubert, Moments Musicaux, Op. 94/1 (publ. 1828)]." Journal of Music Theory 12/2: 222-39.

—. 1969. "More about Schubert's Op. 94/1." Journal of Music Theory 13/2: 218-29.

—. 1970. "Landini's Treatment of Consonance and Dissonance: A Study of FourteenthCentury Counterpoint." Music Forum 2: 130-86.

Schenker, Heinrich. 1906. Harmonielehre. Stuttgart, Germany: Cotta. Trans. by Elisabeth Mann Borgese as Harmony, ed. Oswald Jonas (Chicago: University. of Chicago Press, 1954).

—. 1921. "Von der Sendung des deutschen Genies." Der Tonwille 1: 3-21.

—. 1930. "Vermischtes: Gedanken über die Kunst und ihre Zusammenhänge im Allgemeinen." Das Meisterwerk in der Musik 3.

- 1932. Fünf Urlinie-Tafeln / Five Analyses in Sketchform. Vienna: Universal; and New York: David Mannes Music School.

- 1935. Der Freie Satz. Vienna: Universal, 1935. Translated and ed. by Ernst Oster as Free Composition (Der Freie Satz) (New York: Longman, 1979).

Schweiger, Hertha. 1940. "Changing Trends in Musicology." Bulletin of the American Musicological Society 4: 9.

Sessions, Roger. 1935. "Heinrich Schenker's Contribution." Modern Music 12/4: 17078.

—. 1938a. [Review of Schenker, Der Freie Satz]. Modern Music 15/3: 192-97.

- 1938b. "The Function of Theory." Modern Music 15/4: 257-62.

Silberman, Israel. 1949. A Comparative Study of Four Theories of Chord Function. Ph.D. thesis, Columbia University.

Slatin, Sonia. 1967. The Theories of Heinrich Schenker in Perspective. Ph.D. thesis, Columbia University.

Travis, Roy. 1959. "Toward[s] a New Concept of Tonality?" Journal of Music Theory 3/2: 257-84. 
—. 1966. "Directed Motion in [Two Brief Piano Pieces by] Schoenberg and Webern." Perspectives of New Music 4/2: 85-89.

—. 1974. "Analysis Symposium: Webern, Orchestral Pieces (1913), Movement I ('Bewegt')." Journal of Music Theory 18/1: 6-12.

Weisse, Hans. 1936. "The Music Teacher's Dilemma." Volume of Proceedings of the Music Teachers National Association [for the Meeting of Dec. 1935]: 122-37. Reprinted in Theory and Practice 10/1-2 (1985): 29-48.

Westergaard, Peter. 1962. "Some Problems in Rhythmic Theory and Analysis." Perspectives of New Music 1/1: 180-91.

- 1975. An Introduction to Tonal Theory. New York: Norton.

Yeston, Maury. 1974. The Stratification of Musical Rhythm. Ph.D. thesis, Yale University.

Zuckerkandl, Victor. 1945. "Theoretical Harmony and the Understanding of Music." Bulletin of the American Musicological Society 8: 17-18. 